\title{
Methods for Estimating Regional Coefficient of Skewness for Unregulated Streams in New England, Based on Data Through Water Year 2011
}

Scientific Investigations Report 2017-5037 



\section{Methods for Estimating Regional Coefficient of Skewness for Unregulated Streams in New England, Based on Data Through Water Year 2011}

By Andrea G. Veilleux, Phillip J. Zariello, Glenn A. Hodgkins, Elizabeth A. Ahearn, Scott A. Olson, and Timothy A. Cohn

Scientific Investigations Report 2017-5037 


\title{
U.S. Department of the Interior DAVID BERNHARDT, Secretary
}

\section{U.S. Geological Survey James Reilly II, Director}

\author{
U.S. Geological Survey, Reston, Virginia: 2019
}

For more information on the USGS - the Federal source for science about the Earth, its natural and living resources, natural hazards, and the environment-visit https://www.usgs.gov or call 1-888-ASK-USGS.

For an overview of USGS information products, including maps, imagery, and publications, visit https://store.usgs.gov.

Any use of trade, firm, or product names is for descriptive purposes only and does not imply endorsement by the U.S. Government.

Although this information product, for the most part, is in the public domain, it also may contain copyrighted materials as noted in the text. Permission to reproduce copyrighted items must be secured from the copyright owner.

Suggested citation:

Veilleux, A.G., Zariello, P.J., Hodgkins, G.A., Ahearn, E.A., Olson, S.A., and Cohn, T.A., 2019, Methods for estimating regional coefficient of skewness for unregulated streams in New England, based on data through water year 2011: U.S. Geological Survey Scientific Investigations Report 2017-5037, 29 p., https://doi.org/10.3133/sir20175037.

ISSN 2328-0328 (online) 


\section{Contents}

Abstract

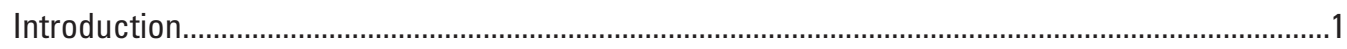

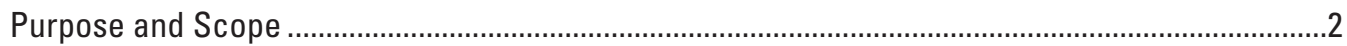

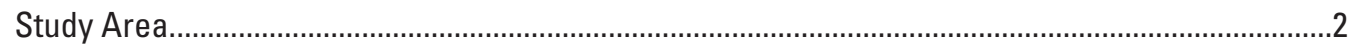

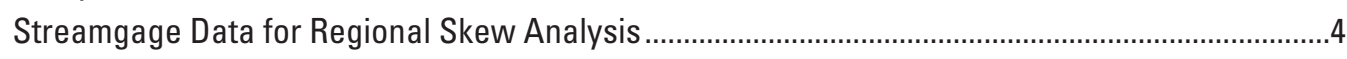

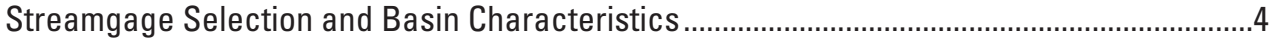

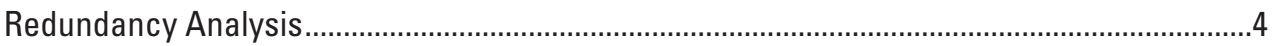

Analytical Methods To Generate Regional Skew...................................................................

Expected Moments Algorithm (EMA) Analysis .........................................................................

Multiple Grubbs-Beck Test for Detecting Potentially Influential Low Outliers.........................5

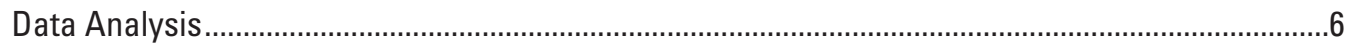

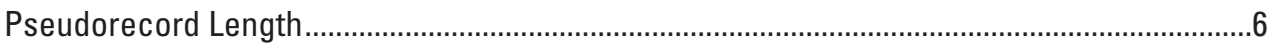

Unbiasing the At-Site Estimators .....................................................................................

Estimating the Mean Square Error of the Skew …….......................................................

Cross-Correlation Models ..................................................................................................

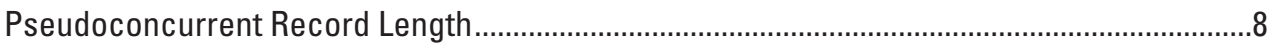

New England Cross-Correlation Model ..................................................................................8

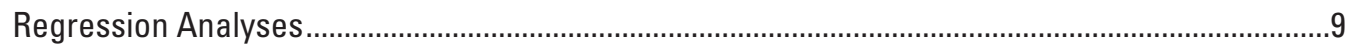

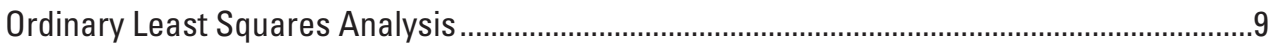

Weighted Least Squares Analysis ...........................................................................................

Generalized Least Squares Analysis ....................................................................................11

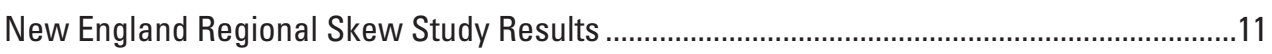

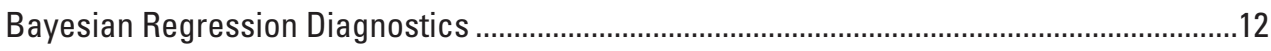

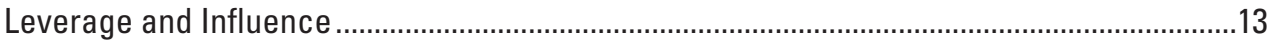

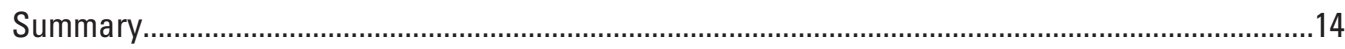

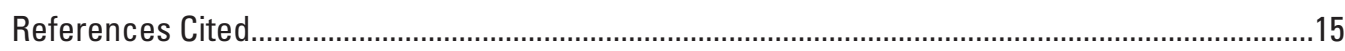

Appendix 1. Assessment of New England Regional Skew Constant Model Through Monte Carlo Realizations .......................................................................................................23

\section{Figures}

1. Map showing streamgages used in the regional skew analysis for New England ..........3

2. Graphs showing cross correlation of annual peak flow in the New England skew study......

\section{Tables}

1. Streamgages in Connecticut, Maine, Massachusetts, New Hampshire, Rhode Island, Vermont, and easternmost New York used in the New England regional skew analysis

2. Regional skew model and model fit for New England regional skew constant model...12

3. Pseudoanalysis of variance for the New England regional skew constant model.........12

4. Streamgages with high influence in the New England regional skew constant model 


\section{Conversion Factors}

U.S. customary units to International System of Units

\begin{tabular}{|c|c|c|}
\hline Multiply & By & To obtain \\
\hline inch (in.) & 2.54 & centimeter $(\mathrm{cm})$ \\
\hline foot $(\mathrm{ft})$ & 0.3048 & meter $(\mathrm{m})$ \\
\hline mile (mi) & 1.609 & kilometer $(\mathrm{km})$ \\
\hline
\end{tabular}

\section{Datum}

Vertical coordinate information is referenced to the North American Vertical Datum of 1988 (NAVD 88).

Horizontal coordinate information is referenced to the North American Datum of 1983 (NAD 83).

Elevation, as used in this report, refers to distance above the vertical datum.

\section{Abbreviations}

$\begin{array}{ll}\text { AEP } & \text { annual exceedance probability } \\ \text { B17B } & \text { Bulletin 17B (Interagency Advisory Committee on Water Data, 1982) } \\ \text { B-GLS } & \text { Bayesian generalized least squares } \\ \text { B-WLS } & \text { Bayesian weighted least squaresEMA expected moments algorithm } \\ \text { GAGES II } & \text { Geospatial Attributes of Gages for Evaluating Streamflow, version II } \\ \text { GLS } & \text { generalized least squares } \\ \text { LP3 } & \text { log-Pearson type III [distribution] } \\ \text { MGB } & \text { multiple Grubbs-Beck [test] } \\ \text { MSE } & \text { mean squared error } \\ \text { OLS } & \text { ordinary least squares } \\ \text { PILF } & \text { potentially influential low flood } \\ \text { USGS } & \text { U.S. Geological Survey } \\ \text { WLS } & \text { weighted least squares }\end{array}$




\title{
Methods for Estimating Regional Coefficient of Skewness for Unregulated Streams in New England, Based on Data Through Water Year 2011
}

\author{
By Andrea G. Veilleux, Phillip J. Zarriello, Glenn A. Hodgkins, Elizabeth A. Ahearn, Scott A. Olson, and \\ Timothy A. Cohn
}

Abstract

The magnitude of annual exceedance probability floods is greatly affected by the coefficient of skewness (skew) of the annual peak flows at a streamgage. Standard flood frequency methods recommend weighting the station skew with a regional skew to better represent regional and stable conditions. This study presents an updated analysis of a regional skew for New England developed using a robust Bayesian weighted and generalized least squares regression model. Nineteen explanatory variables for 153 streamgages were tested in the regression analysis, but none were statistically significant and, as a result, a constant model was selected to define the regional skew for New England. The constant model for the New England region has, in log units, a skew of 0.37 , a model error variance of 0.13 , and an average variance of prediction at a new site of 0.14 . An assessment of the selected regional skew model was conducted using a Monte Carlo analysis. The Monte Carlo simulations reveal that the perceived pattern in the station skews among the 153 streamgages is an artifact of the sample variability and the covariance structure of the errors.

\section{Introduction}

Bulletin 17B (B17B; Interagency Advisory Committee on Water Data, 1982) provides a consistent, objective, reproducible method for flood frequency analysis; B17B recommends the use of the log-Pearson type III (LP3) distribution to fit a series of annual maximum flood peaks to obtain estimates of annual exceedance probability (AEP) discharges at streamgages. This distribution, in the specific case of flood frequency analysis, is described by three moments: the mean, the standard deviation, and the skewness coefficient (skew) of the logarithms of the flow. This third moment, skew, is a measure of the asymmetry of the annual peak flow distribution and can have a large effect on the estimated magnitude of floods for a given AEP. The traditional sample estimator of skew is very sensitive to extreme events, such as large floods or unusually small values, as they cause a sample to be highly skewed, or asymmetrical. Thus, in flood frequency analysis, skew becomes important because interest is focused on the right-hand tail (largest flows) of the distribution. B17B recommends using a weighted average of the station skew and a regional skew; a weighted skew reduces the sensitivity of station skew to extreme events, particularly for streamgages with short records. In addition, B17B supplies a map (Interagency Advisory Committee on Water Data, 1982, pl. I) containing estimated generalized (or regional) skews for the Nation but recommends using additional methods for developing more accurate estimates of regional skew. Since the map was published in 1976, more than 35 years of additional streamflow data have been accumulated and spatial estimation procedures have been refined (Stedinger and Griffis, 2008).

Tasker and Stedinger (1986) developed a weighted least squares (WLS) procedure for estimating regional skews based on station skews for the logarithms of annual peak discharge data. This method of regional analysis of skew accounts for the precision of the estimated station skew for each streamgage, which depends on the length of the streamgage record and the accuracy of the ordinary least squares (OLS) regional mean skew. More recently, Reis and others (2005), Gruber and others (2007), and Gruber and Stedinger (2008) developed Bayesian generalized least squares (B-GLS) regression models for regional skew analyses. A Bayesian methodology allows for the computation of a posterior distribution of both the regression parameters and the model error variance. When the model error variance is small compared with the sampling error of the station estimates (Reis and others, 2005), the Bayesian posterior distribution provides a more robust description of the model error variance than both the generalized least squares (GLS) method-of-moments and maximumlikelihood point estimates (Veilleux, 2011). WLS regression accounts for the precision of the regional model and the effect of the length of the streamgage record on the variance of skew estimators, whereas B-GLS regression also considers the cross correlations among the estimated station skews. Cross correlations have had a large effect on the precision attributed 
to estimates of different parameters (Feaster and others, 2009; Gotvald and others, 2009; Weaver and others, 2009; Parrett and others, 2011).

The expected moments algorithm (EMA) with multiple Grubbs-Beck (MGB) censoring of low outliers (Cohn and others, 2013) was used to perform flood frequency analysis at streamgages; however, this methodology introduces a complication in the calculation of streamgage record length (and concurrent record length) used to describe the precision of sample estimators. In addition to censoring of low outliers, the EMA uses estimated interval discharges for missing, censored, and historic data because the peak discharges are no longer solely represented by single values. Further, large cross correlations between annual peak discharges at pairs of streamgages can introduce a bias if not properly accounted for. To account for these complications, an alternate regression procedure was developed to provide stable, unbiased results for determining regional skew (Veilleux, 2011; Lamontagne and others, 2012; Veilleux and others, 2012). This alternate procedure is referred to as the Bayesian WLS/Bayesian GLS (B-WLS/B-GLS) regression framework (Veilleux, 2011; Veilleux and others, 2011, 2012). The B-WLS/B-GLS procedure uses an OLS analysis to fit an initial regional skew model that is then used to generate a stable regional skew estimate for each streamgage. That stable regional estimate is the basis for computing the variance of each station skew employed in the WLS analysis. Next, the B-WLS procedure is used to generate estimates of the regional skew model parameters. Finally, the B-GLS procedure is used to estimate the precision of the WLS parameter values, to estimate the model error variance and its precision, and to compute various diagnostic statistics.

\section{Purpose and Scope}

The primary purpose of this report is to describe the methods and the results of a regional skew analysis for New England (Connecticut, Maine, Massachusetts, New Hampshire, Rhode Island, and Vermont). This report also includes details of the existing data for the 186 streamgages that were evaluated for use in the regional skew analysis, including annual peak discharges, as well as selected basin characteristics. The EMA with MGB censoring of potentially influential low floods was used to compute moments of the logarithms for the LP3 distribution to determine an at-site skew at each streamgage for use in the regional skew analysis. The B-WLS/B-GLS regression method is described in detail along with diagnostics for analyzing the B-WLS/B-GLS results.

\section{Study Area}

The study area for the New England regional skew analysis consists of the entire States of Connecticut, Maine,
Massachusetts (excluding Cape Cod and the islands), New Hampshire, Rhode Island, Vermont, and the eastern most part of New York. The region spans about 500 miles from southeastern Connecticut to northern Maine. A total of 186 streamgages were evaluated for use in the analysis (fig. 1). Streamgage basin characteristics described below were obtained from the Geospatial Attributes of Gages for Evaluating Streamflow version II (GAGES II) database (Falcone, 2011).

The geomorphology of New England is described as hills and mountains that slope into valleys or coastal lowlands (Denny, 1982). Mountainous areas (elevations greater than 1,600 feet [ft]) are found in the Green Mountains of Vermont, the White Mountains of New Hampshire, and isolated peaks such as Mount Katahdin in Maine, all of which are part of the Northeastern Highlands level III ecoregion (U.S. Environmental Protection Agency, 2012, 2013); this ecoregion consists of most of Vermont, New Hampshire, western Maine, western Massachusetts, and northwestern Connecticut. The Northeastern Coastal Zone ecoregion consists of all of Rhode Island, most of Connecticut, central and eastern Massachusetts, southeastern New Hampshire, and far southeastern Maine, and central-eastern and northeastern Maine make up the Acadian Plains and Hills ecoregion. The Northeastern Coastal Zone and Acadian Plains and Hills have gently rolling hills with incised valleys. Overall, the mean basin elevation at the streamgages used in the analysis ranged from 25 to $1,005 \mathrm{ft}$ (average $273 \mathrm{ft}$ ), relief ranged from 36 to $1,813 \mathrm{ft}$ (average $436 \mathrm{ft}$ ), and basin slopes ranged from 1.2 to 35 percent (average 8.4 percent). The study area excludes southeasternmost Massachusetts and Cape Cod because they are in the Atlantic Coastal Pine Barrens ecoregion, which is characterized by relatively low relief with deep coarsegrained deposits and a water-table surface at depth. These characteristics cause streamflow to respond uniquely to storms from other parts of New England and, in addition, little streamflow information is available in this area to support inclusion into the New England regional skew model.

Climate in New England is characterized as being humid continental with temporal and spatial variations caused by the interchange of air masses from the South and the Midwest and from the north (National Oceanic and Atmospheric Administration, 2013). The exchange of air masses leads to frontal systems that, coupled with wet antecedent conditions, often produce the peak flows of the year. Isolated intense storms from these systems also produce flooding, particularly in small basins. Hurricanes, remnants of hurricanes, and tropical storms that never develop to hurricane strength are major causes of flooding in southern New England (National Oceanic and Atmospheric Administration, undated). These storms typically originate in the central Atlantic Ocean and follow a track along the eastern United States up through New England.

In general, precipitation is evenly distributed throughout the year. On the basis of data collected between 1981 and 2010 (Northeast Regional Climate Center, 2014), mean annual 


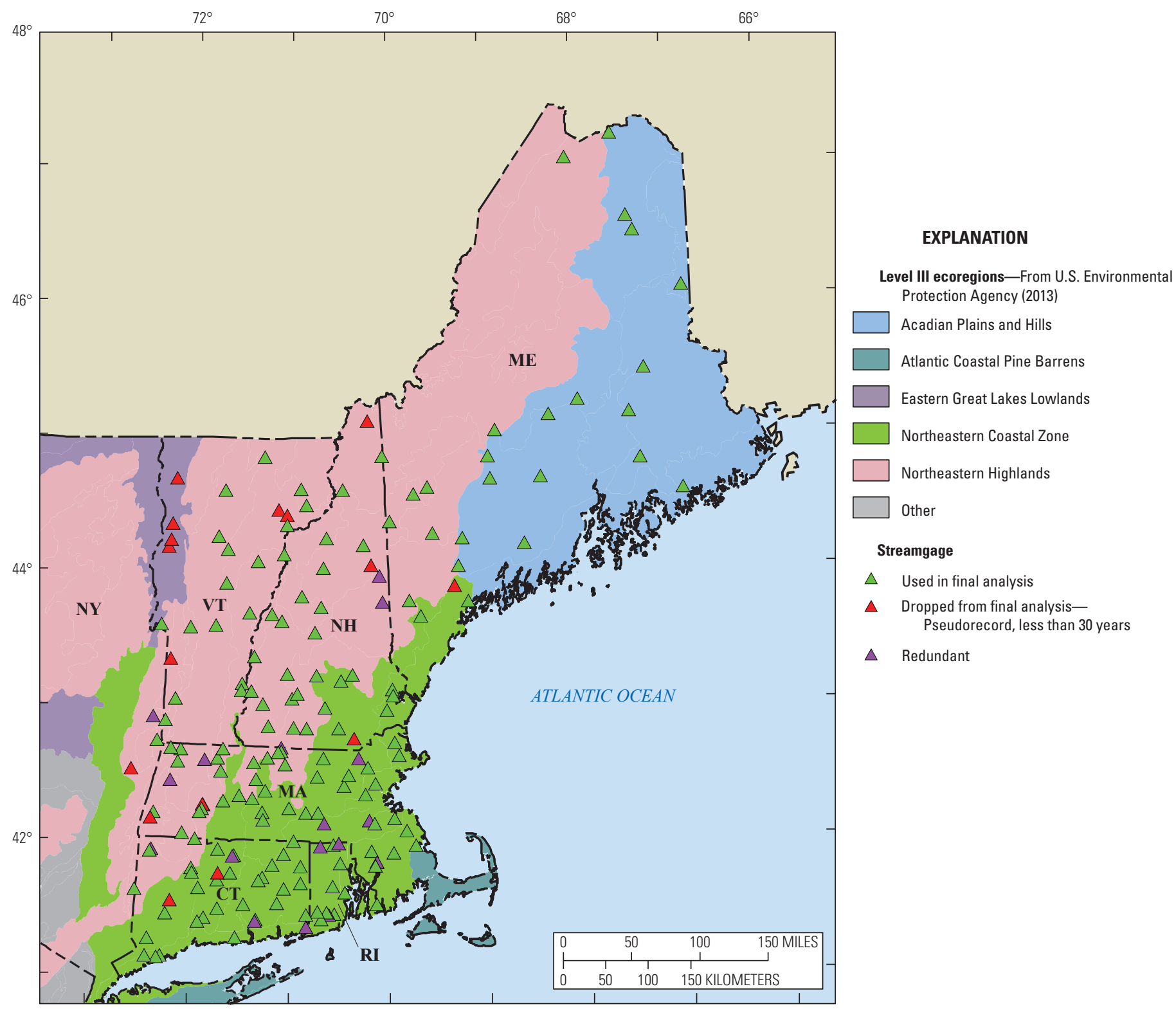

Base from U.S. Environmental Protection Agency, 2011

Figure 1. Streamgages used in the regional skew analysis for New England. Streamgages that were not used in the final analysis because of redundancy or insufficient pseudo record length are also shown.

precipitation ranged from 38 inches per year in northern Maine to 50 inches per year in southern New England. Mean annual temperatures ranged from 38 degrees Fahrenheit $\left({ }^{\circ} \mathrm{F}\right)$ in northern Maine to $50^{\circ} \mathrm{F}$ in southern New England. Because of the combination of weather conditions, more precipitation falls as snow and accumulates during the winter months in northern New England (about 20 to 120 inches [in.]). Snowmelt combined with late-winter or spring rainfall often yields the highest annual peak flows of the year in the northern part of New England. Mean precipitation for streamgage basins in the study area ranged from 37 to $74 \mathrm{in}$. (average $48 \mathrm{in}$.), and the percentage of precipitation that fell as snow ranged from 20 to 44 percent (average 31 percent).
Land use and land cover in New England range from highly developed in and near major metropolitan centers to predominantly forest. Most heavily developed areas are in eastern and southern New England; basins considered highly urbanized were excluded from the study. Land use in the streamgage basins used in the study ranged from 13 to 99 percent (average 69 percent) forested, from 0 to 12 percent (average 0.5 percent) high density urban, 0 to 37 percent (average 2.4 percent) medium-density urban, and 0 to 25 percent (average 3.9 percent) low-density urban. Basin area classified as open water and wetlands ranged from 0 to 7.7 percent (average 1.5 percent) and 0 to 24 percent (average 6.8 percent), respectively (Falcone, 2011). 


\section{Streamgage Data for Regional Skew Analysis}

Data preparation for the regional skew analysis included selection of streamgages and corresponding basin characteristics as well analyses of AEPs to estimate the skew at each streamgage. The AEP analyses were performed using the EMA with the MGB test for potentially influential low floods.

\section{Streamgage Selection and Basin Characteristics}

The New England regional skew analysis used data for 186 U.S. Geological Survey (USGS) streamgages (table 1, in back of report; Wagner and Veilleux, 2019) that have essentially unregulated annual peak flow records through water year ${ }^{1} 2011$; in total, data were used for 36 streamgages in Connecticut, 26 streamgages in Maine, 51 streamgages in Massachusetts, 43 streamgages in New Hampshire, 13 streamgages in Rhode Island, 14 streamgages in Vermont, and 3 streamgages in New York. Annual peak flow data for these streamgages were obtained from the USGS National Water Information System (U.S. Geological Survey, 2014a). Only those streamgages included in the GAGES II database maintained by the USGS were considered for the study. The GAGES II database consists of a subset of USGS streamgages with at least 20 years of discharge record since 1950 or that were active as of water year 2009 and whose watersheds lie entirely within the United States (Falcone, 2011). Only streamgages that are included in the GAGES II database in the New England regional skew study were used because this subset provided a consistent set of basin characteristics across the region. The basin characteristics selected for use to potentially help explain the variation in station skew in the New England study region include morphometric (drainage area, mean basin slope, mean basin elevation, and basin compactness ratio), climatological (mean annual precipitation, average annual air temperature, and snow percentage of total precipitation), geologic, land cover (including percent open water, percent lakes/ponds/reservoirs, percent emergent herbaceous wetlands, percent woody wetlands, percent impervious surface; percent of watershed covered by dominant potential natural vegetation), hydrologic (sinuosity of mainstem stream line, and base flow index), and other characteristics. In addition to basin characteristics obtained from the GAGES II database, the 50th percentile maximum seasonal snow depth was determined from Cember and Wilks (1993, map 56) and the flood flow peaks caused by hurricanes were identified from local records and knowledge.

${ }^{1} \mathrm{~A}$ water year is the 12 -month period beginning October 1 and ending September 30 . It is designated by the year in which it ends.

\section{Redundancy Analysis}

Redundancy results when the drainage basins of two streamgages are nested, meaning that one is contained inside the other, and also of similar size. Instead of providing two spatially independent observations that depict how drainage basin characteristics are related to skew (or the magnitude of the AEP flow), these two basins will have exceedingly similar hydrologic responses to a given storm and thus represent only one spatial observation. When redundant streamgages are both included, a statistical analysis incorrectly represents the value of the information contained in the regional dataset (Gruber and Stedinger, 2008). To determine if two streamgages are redundant and thus represent the same hydrologic conditions, two types of information are considered: whether the basins of the streamgages are nested and the ratio of the drainage areas for the two basins.

The standardized distance $(S D)$ is used to determine the likelihood the basins are nested. The standardized distance between two basin centroids $\left(S D_{i j}\right)$ is defined as follows:

$$
S D_{i j}=\frac{D_{i j}}{\sqrt{0.5\left(\text { DRNAREA }_{i}+\text { DRNAREA }_{j}\right)}}
$$

where

$D_{i j} \quad$ is the distance between centroids of basin $i$ and basin $j$,

$D_{D N A R E A_{i}} \quad$ is the drainage area at streamgage $i$, and $D R N A R E A_{j} \quad$ is the drainage area at streamgage $j$.

The drainage area ratio $(D A R)$ is used to determine if two nested basins are sufficiently similar in size to conclude that they are essentially or are at least in large part the same watershed for the purposes of developing a regional hydrologic model. The DAR (Veilleux, 2009) is defined as follows:

$$
D A R=\operatorname{Max}\left[\frac{D R N A R E A_{i}}{D_{R N A R E A_{j}}}, \frac{D R N A R E A_{j}}{D_{R N A R E A_{i}}}\right]
$$

where

Max is the maximum of the two values in brackets, $D R N A R E A_{\mathrm{i}} \quad$ is the drainage area at streamgage $i$, and $D R N A R E A_{\mathrm{j}} \quad$ is the drainage area at streamgage $j$.

Previous studies suggest that, for the purposes of determining regional skew, streamgage pairs having $S D$ less than or equal to 0.50 and $D A R$ less than or equal to 5 were likely to be redundant. However, if the drainage area ratio is large enough, even if the basins of the streamgages are nested, then they will reflect different hydrologic responses because storms of different sizes and duration will typically affect each site differently.

Table 1 shows the results of the redundant streamgage screening on the New England regional skew data. Note that the information in table 1 is also available as USGS data release (Wagner and Veilleux, 2019).

All possible combinations of streamgage pairs from the 186 streamgages were considered in the redundancy analysis. In order to be conservative, all streamgage pairs with basin characteristics of $S D<0.75$ and $D A R<8$ were identified as possible 
redundant streamgage pairs. All streamgages identified as possibly redundant were then investigated to determine if, in fact, the basin of one streamgage of the pair is nested inside the other. The procedure identified 37 possible redundant streamgage pairs; of these, 34 streamgage pairs were found to be redundant and 17 streamgages were removed from the analysis (table 1, in back of report; streamgages indicated as "No-R"). The other three streamgage pairs identified as potentially redundant were determined to be independent and kept in the analysis, leaving 169 streamgages for the regional skew study.

\section{Analytical Methods To Generate Regional Skew}

The skew is very sensitive to extreme events, such as large floods, because they can cause the position of a sample within the distribution to be highly skewed, or asymmetrical. Thus, in flood frequency analysis, the measurement of skew becomes significant and interest is focused on the right-tail of the distribution. However, the span of recorded flood data at a given streamgage is usually too short to provide a highly reliable estimate of the skew. To improve the precision of the skewness estimator, B17B (Interagency Advisory Committee on Water Data, 1982) advises combining a regional skew with the at-site skew (Beard, 1974; Hardison, 1975; Tasker, 1978; McCuen, 1979, 2001; Griffis and Stedinger, 2007b). Griffis and Stedinger (2009b) showed that the B17B weighted skewness estimator (inverse weighting using the mean squared error [MSE] of the skew) results in the estimator with the smallest MSE, provided that the regional skew is unbiased and independent of the at-site skew estimator. Griffis and Stedinger (2007a, 2009a) illustrate the value of a good regional skewness estimator in terms of the precision of flood quantile estimates (Veilleux, 2009).

To improve the regional skew estimate for New England, the at-site skew and its MSE for each streamgage to be used in the regional analysis were determined. For this analysis PeakFQ version 7.0 (Veilleux and others, 2014; U.S. Geological Survey, 2014b) was used to compute the flood frequency analysis because it combines the EMA with the MGB test as an efficient and robust means for estimating skew and MSE.

\section{Expected Moments Algorithm (EMA) Analysis}

The EMA with the MGB test was used to fit the LP3 and compute AEPs and correspondingly the at-site skew and its MSE for the streamgages included in the regional skew analysis. The EMA with the MGB test flood frequency analysis includes at-site estimates of AEP flood flows, which are not included in the report because the focus of this study is to update the regional skews for New England. Logically, however, the next step following a regional skew analysis would be to run the EMA with the MGB test analyses again, weighting the at-site skew with the revised regional skews.
The EMA addresses several methodological concerns identified in the procedures specified by B17B (Interagency Advisory Committee on Water Data, 1982) while retaining the essential structure and moments-based approach of the existing B17B procedures for determining flood frequency. The EMA can accommodate interval data, which simplifies the analysis of datasets containing censored observations, historic data, low outliers, and uncertain data points, while also providing enhanced confidence intervals on the estimated discharges (Veilleux and others, 2014). Unlike B17B, which recognizes two categories of data [systematic peaks (annual peaks observed in the course of the systematic operation of a streamgage) and historic peaks (records of floods that occurred outside the period of regular streamgage operation)], the EMA employs a more general description of flood information for the historical period that includes both systematic and historic peaks (Veilleux and others, 2014). This is accomplished through the use of flow intervals to describe the knowledge of the peak flow $Q_{Y}$ in each year $Y$ and through the use of perception thresholds to describe the range of measurable potential discharges in each year $Y$. It is important to note that for streamgages that have complete periods of record, no low outliers, no censored flood values, and no historic flood information, the EMA with the MGB test method provides identical estimates of the three LP3 moments (mean, standard deviation, and skew) as the standard LP3 method described in B17B (Interagency Advisory Committee on Water Data, 1982; Gotvald and others, 2012). A complete description and application of the algorithm is given in Cohn and others $(1997,2001)$.

\section{Multiple Grubbs-Beck Test for Detecting Potentially Influential Low Outliers}

B17B (Interagency Advisory Committee on Water Data, 1982) recommends the use of the Grubbs-Beck test (Grubbs and Beck, 1972) to detect low outliers in flood frequency analysis. As described by Cohn and others (2013), the MGB test is a generalization of the Grubbs-Beck method that allows for a standard procedure for identifying multiple potentially influential low floods. In flood frequency analysis, potentially influential low floods are annual peaks that meet three criteria: their magnitude is much smaller than the flood quantile of interest, they occur below a statistically significant break in the flood frequency plot, and they have excessive influence on the estimated frequency of large floods. When an observation is identified as a potentially influential low flood, all values smaller than that flood are also categorized as potentially influential low floods. Identifying potentially influential low floods and recording them as censored peaks can greatly improve estimator robustness with little or no loss of efficiency. Thus, the use of the MGB test can improve the fit of the small AEPs (larger magnitude floods) by minimizing lack-of-fit due to unimportant potentially influential low floods in an annual peak series (Cohn and others, 2013; Veilleux and others, 2014). 


\section{Data Analysis}

Prior to performing a B-WLS/B-GLS regional skew analysis, three data analysis procedures must first be completed. This section describes the steps for the calculations for pseudorecord length for each streamgage given the number of censored observations and concurrent record lengths, the corrections for structural bias in the at-site estimate of skew and its MSE, and the development of a cross-correlation model of concurrent annual peak discharges between streamgages.

\section{Pseudorecord Length}

The record length of the annual peak series at each streamgage is used in the regional skew study in several steps, including unbiasing the at-site skew and its MSE, determining the concurrent record length between two streamgages, and computing the cross correlation of the at-site skews (see "Cross-Correlation Models" section). Because the dataset includes censored data and historic information, the effective record length used to compute the precision of the skewness estimators is no longer simply the number of annual peak discharges at a streamgage. Instead, a more complex calculation is used to take into account the availability of historic information and censored values. Although historic information and censored peaks provide valuable information, they often provide less information than an equal number of years with systematically recorded peaks (Stedinger and Cohn, 1986). The historic peak itself may be known imprecisely, and a number of years of record may simply be known to have peak values less than the historic peak. The following calculations provide a pseudorecord length $\left(P_{R L}\right)$ that appropriately accounts for all peak discharge data types available for a streamgage. The pseudorecord length equals the systematic record length if such a complete record, with no interval data, is all that is available for a streamgage.

The first step in computing $P_{R L}$ is to conduct an EMA analysis with all available information, including historic information and censored peaks $\left(E M A_{C}\right)$. From this $E M A_{C}$, the at-site skew without regional information $\left(\hat{G}_{C}\right)$ and the MSE of that skewness estimator are extrapolated for each streamgage, as well as the year the historical period begins $\left(Y B_{C}\right)$, the year the historical period ends $\left(Y E_{C}\right)$, and the length of the historical period $\left(H_{C}\right)$ from the following equation:

$$
H_{C}=Y E_{C}-Y B_{C}+1 \text {. }
$$

The second step is to run EMA again with only the systematic peaks $\left(E M A_{s v s}\right)$. From the $E M A_{s y s}$ analysis, the at-site skew without regional information $\left(\hat{G}_{s y s}\right)$ and the MSE of that skew $\left.\operatorname{MSE}\left(\hat{G}_{s y s}\right)\right)$ are extracted, as well as the number of systematic peaks $\left(P_{s y s}\right)$. If no historical or censored data exist for the streamgage, then these values are the same as $\hat{G}_{C}$ and $\operatorname{MSE}\left(\hat{G}_{C}\right)$.

The third step is to represent, from both $E M A_{C}$ and $E M A_{s y s}$, the precision of the skew as two record lengths ( $R L_{C}$ and $R L_{S}$, respectively) based upon the estimated skew and MSE. The corresponding record lengths are calculated using the following equation from Griffis and others (2004) and Griffis and Stedinger (2009b):

$$
\operatorname{MSE}(\hat{G})=\left[\frac{6}{R L}+a(R L)\right] \times\left[1+\left(\frac{9}{6}+b(R L)\right) \hat{G}^{2}+\left(\frac{15}{48}+c(R L)\right) \hat{G}^{4}\right]
$$

where

$$
\begin{array}{cl}
\operatorname{MSE}\left(\hat{G}_{C}\right) & \text { uses } R L_{C} \text { and } \hat{G}_{C}, \\
\operatorname{MSE}\left(\hat{G}_{s y s}\right) & \text { uses } R L_{S} \text { and } \hat{G}_{s y s} \text {, and }
\end{array}
$$

$a(R L), b(R L)$, and $c(R L)$ are calculated as follows:

$$
\begin{gathered}
a(R L)=-\frac{17.75}{R L^{2}}+\frac{50.06}{R L^{6}}, \\
b(R L)=\frac{3.93}{R L^{0.3}}-\frac{30.97}{R L^{0.6}}+\frac{37.1}{R L^{0.9}}, \text { and }
\end{gathered}
$$




$$
c(R L)=-\frac{6.16}{R L^{0.56}}+\frac{36.83}{R L^{1.12}}-\frac{66.9}{R L^{1.68}} .
$$

Next, the difference $\left(R L_{\text {diff }}\right)$ between $R L_{C}$ and $R L_{S}$ is used as a measure of the extra information provided by the historic and censored information that was included in the $E M A_{C}$ analysis but not in the $E M A_{s y s}$ analysis:

$$
R L_{\text {diff }}=R L_{C}-R L_{s y s} .
$$

The $P_{R L}$ for the entire record at the streamgage is calculated using $R L_{\text {diff }}$ and the number of systematic peaks $\left(P_{s y s}\right)$ as follows:

$$
P_{R L}=R L_{\text {diff }}+P_{\text {sys }} .
$$

$P_{R L}$ must be nonnegative. If no historic or censored data exist for the streamgage, $P_{R L}$ equals $P_{s y s}$. If $P_{R L}$ is greater than $H_{C}$, then $P_{R L}$ is set equal to $H_{C}$. Also, if $P_{R L}$ is less than $P_{s y s}$, then $P_{R L}$ is set equal to $P_{s y s}$. This ensures that the $P_{R L}$ will not be greater than $H_{C}$ or less than $P_{s y s}$.

The at-site skew is sensitive to extreme events and more accurate estimates can be obtained from longer records (Interagency Advisory Committee on Water Data, 1982). Thus, after ensuring adequate spatial and hydrologic coverage, streamgages with $\mathrm{P}_{R L}$ less than 30 years were removed from the study. Of the 169 sites remaining after removing the 17 redundant sites, 16 were removed because their $\mathrm{P}_{R L}$ is less than 30 years (table 1, in back of report; indicated as "no-P"), leaving 153 streamgages from which a regional skewness model for New England was developed.

\section{Unbiasing the At-Site Estimators}

The at-site skew estimates become unbiased by using the correction factor developed by Tasker and Stedinger (1986) and employed in Reis and others (2005). The unbiased at-site skew for streamgage $i\left(\hat{\gamma}_{i}\right)$ is computed from $P_{R L}$ and the at-site skew $\left(G_{c, i}\right)$ computed by EMA for streamgage $i$ using the following equation:

$$
\hat{\gamma}_{i}=\left[1+\frac{6}{P_{R L, i}}\right] G_{i}
$$

where

$$
\begin{aligned}
P_{R L, i} & \text { is the pseudorecord length for streamgage } i \text { (eq. 9), and } \\
G_{i} & \text { is the biased at-site skew estimate for streamgage } i \text {; for the purposes of this } \\
& \text { equation, } G_{i} \text { equals } G_{c, i}
\end{aligned}
$$

The variance of the unbiased at-site skew $\left(\operatorname{Var}\left(\hat{\gamma}_{i}\right)\right)$ includes the correction factor developed by Tasker and Stedinger (1986):

$$
\operatorname{Var}\left(\hat{\gamma}_{i}\right)=\left[1+\frac{6}{P_{R L, i}}\right]^{2} \operatorname{Var}\left(G_{i}\right),
$$

where $\operatorname{Var}\left(G_{i}\right)$ is calculated using the following equation from Griffis and Stedinger (2009b):

where

$$
\operatorname{Var}(\hat{G})=\left[\frac{6}{P_{R L}}+a\left(P_{R L}\right)\right] \times\left[1+\left(\frac{9}{6}+b\left(P_{R L}\right)\right) \hat{G}^{2}+\left(\frac{15}{48}+c\left(P_{R L}\right)\right) \hat{G}^{4}\right]
$$

$$
a\left(P_{R L}\right)=-\frac{17.75}{P_{R L}^{2}}+\frac{50.06}{P_{R L}^{3}},
$$




$$
\begin{aligned}
& b\left(P_{R L}\right)=\frac{3.92}{P_{R L}^{0.3}}-\frac{31.10}{P_{R L}^{0.6}}+\frac{34.86}{P_{R L}^{0.9}} \text {, and } \\
& c\left(P_{R L}\right)=-\frac{7.31}{P_{R L}^{0.59}}+\frac{45.90}{P_{R L}^{1.18}}-\frac{86.50}{P_{R L}^{1.77}} .
\end{aligned}
$$

\section{Estimating the Mean Square Error of the Skew}

There are several ways to estimate the MSE of the at-site skew $\left(M S E_{G}\right)$. The approach used by EMA (from Cohn and others, 2001, eq. 55) generates a first-order estimate of the $M S E_{G}$, which should perform well when interval data are present. Another option is to use the approach described by Griffis and Stedinger (2009b) (the variance as shown in equation 12 is equated to the MSE), employing either the systematic record length or the length of the whole historical period. However, this method does not account for censored data and thus can lead to inaccurate and underestimated $M S E_{G}$. This issue has been addressed by using the $P_{R L}$ instead of the length of the historical period because the $P_{R L}$ reflects the effect of the censored data on the number of systematic peaks. Thus, the unbiased Griffis and Stedinger (2009b) $M S E_{G}$ is used in the regional skew model because it is more stable than the approach by Cohn and others (2001) and relatively independent of the at-site skew. This methodology has been used in recently published regional skew studies (Parrett and others, 2011; Eash and others, 2013; Paretti and others, 2014; Southard and Veilleux, 2014).

\section{Cross-Correlation Models}

A critical step for a GLS analysis is estimation of the cross correlation among at-site skews. Martins and Stedinger (2002) used Monte Carlo simulations to derive a relation between the cross correlation of the skew at two streamgages ( $i$ and $j$ ) as a function of the cross correlation of concurrent annual peak flows $\left(\rho_{i j}\right)$ :

$$
\hat{\rho}\left(\hat{\gamma}_{i}, \hat{\gamma}_{j}\right)=\operatorname{Sign}\left(\hat{\rho}_{i j}\right) c f_{i j}\left|\hat{\rho}_{i j}\right|^{K}
$$

where

$$
\begin{aligned}
\hat{\gamma}_{i} \text { and } \hat{\gamma}_{j} & \text { are the unbiased at-site skew estimate for } \\
& \text { streamgages } i \text { and } j, \text { respectively; } \\
\hat{\rho}_{i j} & \text { is the estimated cross correlation of } \\
& \text { concurrent annual peak flow for } \\
& \text { streamgages } i \text { and } j ; \\
\kappa & \text { is a constant between } 2.8 \text { and 3.3; and } \\
c f_{i j} & \text { is a factor that accounts for the sample size } \\
& \text { difference between streamgages and their } \\
& \text { concurrent record length and is defined as } \\
& \text { follows: }
\end{aligned}
$$

$$
c f_{i j}=\frac{C Y_{i j}}{\sqrt{\left(P_{R L, i}\right)\left(P_{R L, i}\right)}} .
$$

where

$C Y_{i j} \quad$ is the pseudorecord length of the period of concurrent record (pseudoconcurrent record length); and

$P_{R L, i}$ and $P_{R L, j} \quad$ are the pseudorecord length corresponding to streamgages $i$ and $j$, respectively, as calculated from equation 9 .

\section{Pseudoconcurrent Record Length}

The $C Y_{i j}$ (eq. 17) is used to compute cross correlation between streamgages. Because both censored and historic data are used, the effective concurrent record length calculation is more complex than determining in which years the two streamgages both have recorded systematic peaks.

The years of historical record in common between the two streamgages are determined first. For the years in common, with beginning year $\mathrm{YB}_{i j}$ and ending year $\mathrm{YE}_{i j}$, the following equation is used to calculate the concurrent years of record between streamgages $i$ and $j$.

$$
C Y_{i j}=\left(Y E_{i j}-Y B_{i j}+1\right)\left(\frac{P_{R L, i}}{H_{C, i}}\right)\left(\frac{P_{R L, j}}{H_{C, j}}\right),
$$

where

$Y B_{i j} \quad$ is the beginning year of the common historical record for streamgages $i$ and $j$;

$Y E_{i j} \quad$ is the ending year of the common historical record for streamgages $i$ and $j$;

$P_{R L, i}$ and $P_{R L, j} \quad$ are the pseudorecord length for streamgages $i$ and $j$, respectively; and

$H_{C, i}$ and $H_{C, j} \quad$ are the length of the historical record for streamgages $i$ and $j$, respectively.

The computed pseudoconcurrent record length depends upon the years of historical record in common between the two streamgages, as well as the ratios of the pseudorecord length to the historical record length for each streamgage.

\section{New England Cross-Correlation Model}

A cross-correlation model for the annual peaks in New England was developed using logarithms (base 10) of the annual peak flows from 34 streamgages that generated streamgage pairs with at least 80 years of concurrent systematic peaks, which resulted in 546 streamgage pairs. A logit model, termed the Fisher $\mathrm{Z}$ transformation $(\mathrm{Z})$, provided a convenient transformation of the sample correlations $r_{i j}$ from the $(-1,+1)$ range to the $(-\infty,+\infty)$ range. It was developed as follows:

$$
Z=\log \left(\frac{1+r}{1-r}\right)
$$


where $r$ is a sample correlation.

Various models relating the $\hat{\rho}_{i j}$ to various basin characteristics were considered. The model that was adopted uses only one explanatory variable for estimating the $\hat{\rho}_{i j}$ and is based on the distance, in miles, between basin centroids $\left(D_{i j}\right)$, calculated as follows:

where

$$
\hat{\rho}_{i j}=\frac{\exp \left(2 Z_{i j}\right)-1}{\exp \left(2 Z_{i j}\right)+1},
$$

$$
Z_{i j}=\exp \left(0.83-0.24\left(\frac{D_{i j}^{0.14}-1}{0.14}\right)\right) .
$$

An OLS regression analysis based on 546 streamgage pairs with at least 80 years of concurrent record indicated that the cross-correlation model is as accurate as having 270 years of concurrent annual peaks from which to calculate the cross correlation. The fitted OLS regression relation between $Z_{i j}$ and $D_{i j}$ from the 546 streamgage pairs (fig. $2 A$ ) shows an exponential decline in the cross correlation for streamgages within 50 miles of each other. A similar decline is found in the cross correlation and distance between basin centroids for the untransformed streamgage pairs (fig. $2 B$ ). The cross-correlation model was used to estimate streamgageto-streamgage cross correlations for concurrent annual peak discharges at all streamgage pairs used in the regional skew study.

\section{Regression Analyses}

The B-WLS/B-GLS method (as it appears in Veilleux and others, 2012) is described briefly, followed by the results of applying these methods in the New England regional skew study; details on the method can be found in Veilleux (2011) and Veilleux and others (2011). The method uses an OLS analysis to fit an initial regional skew model that is then used to generate a stable regional skew estimate for each streamgage. That stable regional estimate is the basis for computing the variance of each streamgage skew employed in the WLS analysis. Then, B-WLS is used to generate estimators of the regional skew model parameters (discussed in the "Weighted Least Squares Analysis" section). Finally, B-GLS is used to estimate the precision of the WLS parameter values, to estimate the model error variance and its precision, and to compute various diagnostic statistics.

\section{Ordinary Least Squares Analysis}

The first step in the B-WLS/B-GLS regional skew analysis is the estimation of a regional skew model using OLS. The OLS regional regression yields the parameters and a model that can be used to generate unbiased and relatively stable regional estimates of the skew for all streamgages, as follows:

$$
\tilde{y}_{O L S}=X \hat{\beta}_{O L S}
$$

where

$$
\begin{array}{cl}
\tilde{y}_{O L S} & \text { is the estimated regional skew value; } \\
X & \text { is an }[n \times k] \text { matrix of basin characteristics for } \\
\text { the streamgage; } \\
n & \text { is the number of streamgages; } \\
k & \text { is the number of basin parameters, including } \\
& \text { a column of ones to estimate the constant; } \\
\text { and } & \text { is the }(k \times 1) \text { vector of OLS regression } \\
\hat{\beta}_{O L S} & \text { parameters. }
\end{array}
$$

These $\tilde{y}_{O L S}$ values are then used to calculate unbiased regional skew variances for all streamgages in New England using the equations reported in Griffis and Stedinger (2009b). These regional skew variances are based on the regional OLS estimator of the skew instead of the at-site skew estimator, thus making the weights in the subsequent steps relatively independent of the at-site skew estimates.

\section{Weighted Least Squares Analysis}

A WLS analysis is used to develop estimators of the regression skew for each regional skew model. The WLS analysis explicitly reflects variations in record length but intentionally neglects cross correlations, thereby avoiding the problems experienced with GLS parameter estimators (Veilleux, 2011; Veilleux and others, 2011).

The first step in the WLS analysis is to estimate the model error variance $\left(\sigma_{\delta, B-W L S}^{2}\right)$ using an iterative approach, as described by Reis and others (2005). Using a B-WLS approach to estimate the model error variance avoids the possible pitfall of estimating the model error variance as zero, which can occur when using method-of-moments WLS. It is important to note that the Bayesian analysis produces an estimate of the distribution of the model error variance; however, only the mean $\sigma_{\delta, B-W L S}^{2}$ estimator is considered in this analysis.

Given the $\sigma_{\delta, B-W L S}^{2}$ estimator, a diagonal covariance matrix $\left[\Lambda_{W L S}\left(\sigma_{\delta, B-W L S}^{2}\right)\right]$ is created as follows:

$$
\Lambda_{W L S}\left(\sigma_{\delta, B-W L S}^{2}\right)=\sigma_{\delta, B-W L S}^{2} I+\operatorname{diag}(\operatorname{Var}[\hat{\gamma}]),
$$

where

$$
\begin{array}{cl}
I & \begin{array}{c}
\text { is an } n \times n \text { identity matrix, } \\
\operatorname{diag}(\operatorname{Var}[\hat{\gamma}]) \\
\text { is the } n \times n \text { matrix containing the variance of } \\
\text { the unbiased at-site skew }\left(\operatorname{Var}\left[\hat{\gamma}_{i}\right]\right) \text { on } \\
\text { the diagonal and zeros on the off-diagonal } \\
\text { directions, and }
\end{array} \\
\sigma_{\delta, B-W L S}^{2} & \begin{array}{l}
\text { is the model error variance for the B-WLS } \\
\text { regression. }
\end{array}
\end{array}
$$



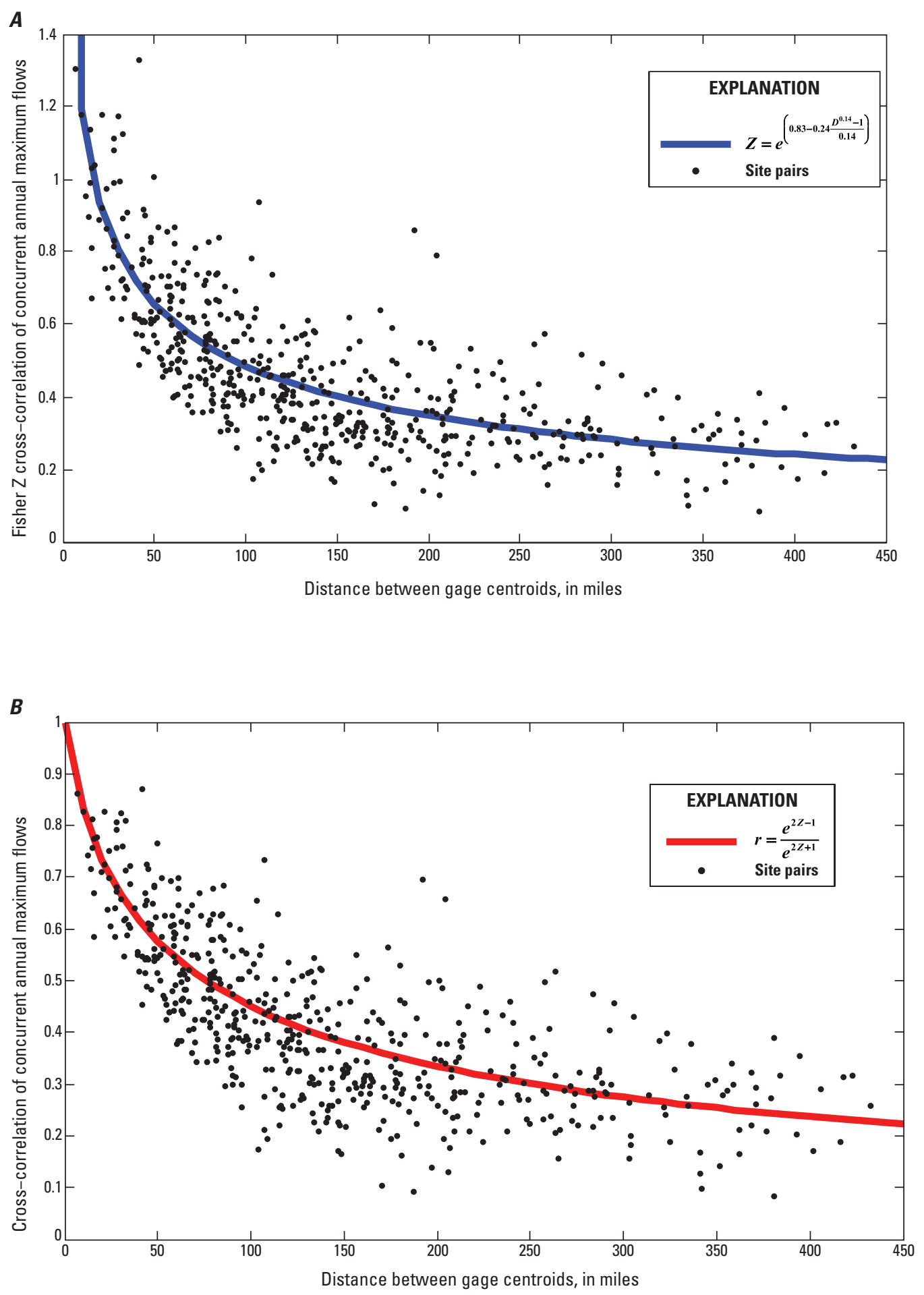

Figure 2. Cross correlation of annual peak flow in the New England skew study. $A$, Relation between Fisher Z-transformed cross-correlation of logarithms of annual peak discharge and distance between basin centroids based on 546 streamgage pairs with concurrent record lengths greater than or equal to 80 years from 34 streamgages in New England. $B$, Relation between untransformed cross-correlation of logs of annual peak discharge and distance between basin centroids based on 546 streamgage pairs with concurrent record lengths greater than or equal to 80 years from 34 streamgages in New England. 
The diagonal elements of the covariance matrix are the sum of the estimated $\sigma_{\delta, B-W L S}^{2}$ and the $\operatorname{Var}\left[\hat{\gamma}_{i}\right]$, which depends upon on the at-site record length and the estimate of the previously calculated $\tilde{y}_{O L S}$ regional skew. The off-diagonal elements of $\Lambda_{W L S}\left(\sigma_{\delta, B-W L S}^{2}\right)$ are zero because cross correlations between streamgages are not considered in the WLS analysis. Using that covariance matrix, a B-WLS analysis is used to generate the $k \times n$ weight matrix ( $W$ ) of the WLS weights as follows:

$$
W=\left[X^{T} \Lambda_{W L S}\left(\sigma_{\delta, B-W L S}^{2}\right)^{-1} X\right]^{-1} X^{T} \Lambda_{W L S}\left(\sigma_{\delta, B-W L S}^{2}\right)^{-1} .
$$

These weights $(W)$ are used to compute the final estimates of the $k \times 1$-matrix-vector regression parameters $\hat{\beta}_{W L S}$ as follows:

$$
\hat{\beta}_{W L S}=W \hat{\gamma} .
$$

\section{Generalized Least Squares Analysis}

After the regression model $\hat{\beta}_{W L S}$ parameters and $W$ weights are determined with a WLS analysis, the precision of the fitted model and of the regression skews are estimated using a B-GLS regression framework for regional skew developed by Reis and others (2005) with the posterior probability density function for $\sigma_{\delta, B-G L S}^{2}$ being as follows:

$$
\begin{gathered}
f\left(\sigma_{\delta, B-G L S}^{2} \mid \hat{\gamma}, \hat{\beta}_{W L S}\right) \propto \frac{\xi\left(\sigma_{\delta, B-G L S}^{2}\right)}{\sqrt{\mid \Lambda_{G L S}\left(\sigma_{\delta, B-G L S}^{2}\right)}} \times \\
\exp \left[\frac{-0.5\left(\hat{\gamma}-X \hat{\beta}_{W L S}\right)^{T}}{\Lambda_{G L S}\left(\sigma_{\delta, B-G L S}^{2}\right)}\left(\hat{\gamma}-X \hat{\beta}_{W L S}\right)\right],
\end{gathered}
$$

where

$\hat{\gamma} \quad$ represents the skew data, and $\xi\left(\sigma_{\delta, B-G L S}^{2}\right) \quad$ is the exponential prior for the model error variance described by the following equation:

$$
\xi\left(\sigma_{\delta, B-G L S}^{2}\right)=\lambda e^{-\lambda\left(\sigma_{\delta, B-G L S}^{2}\right)}
$$

where $\sigma_{\delta, B-G L S}^{2}>0$. A value of 10 was adopted for lambda $(\lambda)$, corresponding to a mean $\sigma_{\delta, B-W L S}^{2}$ of 0.1 . That exponential prior assigns a 63 percent probability to the interval $[0,0.1]$, 86 percent probability to the interval $[0,0.2]$, and 95 percent probability to the interval $[0,0.3]$.

The mean B-GLS model error variance $\left(\sigma_{\delta, B-G L S}^{2}\right)$ can then be used to compute the precision of the regression parameters $\left(\hat{\beta}_{W L S}\right)$ that were calculated with the WLS weights $W$. The GLS covariance matrix for the WLS estimator $\hat{\beta}_{W L S}$ is as follows:

$$
\sum \hat{\beta}_{W L S}=W \Lambda_{G L S}\left(\sigma_{\delta, B-G L S}^{2}\right) W^{T}
$$

where $\Lambda_{G L S}\left(\sigma_{\delta, B-G L S}^{2}\right)$ is an $n \times n$ GLS covariance matrix calculated as follows:

$$
\Lambda_{G L S}\left(\sigma_{\delta, B-G L S}^{2}\right)=\sigma_{\delta, B-G L S}^{2} I+\sum \hat{\gamma}
$$

where

$$
\begin{array}{cl}
I \quad \text { is an } n \times n \text { identity matrix, } \\
\sum \hat{\gamma} \quad \text { is a full } n \times n \text { matrix that contains the } \\
\text { sampling variances of the } \operatorname{Var}[\hat{\gamma}] \text { and the } \\
\quad \text { covariances of the skew } \hat{\gamma} .
\end{array}
$$

The off-diagonal values of $\sum \hat{\gamma}$ are determined by the cross correlation of concurrent systematic annual peak flows and the $c f_{i j}$ factor (eq. 17; Martins and Stedinger, 2002, eq. 3). When calculating the $c f_{i j}$ factor using the ratio between the number of concurrent peak flows at streamgage pairs and the total number of peak flows at both streamgages, only the systematic records and historic peaks are considered. Thus, any additional information provided by perception thresholds and censored peaks included in the EMA analysis would have been neglected in the calculation of the cross correlation of peak flows and the $c f_{i j}$ factor. Precision metrics include the standard error of the regression parameters $\left[S E\left(\hat{\beta}_{W L S}\right)\right]$, the model error variance $\left(\sigma_{\delta, B-G L S}^{2}\right)$, the pseudocoefficient of determination (pseudo- $R_{\delta}^{2}$ ), as well as the average variance of prediction at a streamgage not used in the regional model $\left(A V P_{n e w}\right)$. The pseudo- $R_{\delta}^{2}$, describes the estimated fraction of the variability in the true skew from streamgage to streamgage explained by each model (Gruber and others, 2007; Parrett and others, 2011).

\section{New England Regional Skew Study Results}

All available basin characteristics compiled for the New England regional skew study using the B-WLS/B-GLS regression methodology were initially considered as possible explanatory variables and evaluated but none produced a pseudo- $R_{\delta}^{2}$ greater than 10 percent, indicating that the basin characteristics did not explain the variation in at-site skews within New England. Hence, a constant model, one that does not vary with basin characteristics, was developed to predict the regional skew for New England from the sample mean of 153 streamgages with at least 30 years of $P_{R L}$ (table 2); this model produced a skew of 0.37 , the only statistically significant skew for the region.

The constant model does not explain any variability in the skew, so the pseudo- $R_{\delta}^{2}$ equals 0 . However, the addition of any of the available basin characteristics or combination thereof did not produce a pseudo- $R_{\delta}^{2}$ greater than 13 percent. This indicates that the inclusion of basin characteristics as explanatory variables in the regression help explain only 13 percent of the total variability in the true skew for New England. Thus, the addition of basin characteristics is not warranted because the increased model complexity does not result 
Table 2. Regional skew model and model fit for New England regional skew constant model.

[Pseudocoefficient of variation (pseudo- $R_{\delta}^{2}$ ) describes the percentage of the variability in the true skews explained by each model (Gruber and others, 2007). $\sigma_{\delta}^{2}$, model error variance; $A S E V$, average sampling error variance; $A V P_{n e w}$, average variance of prediction for a new streamgage; $\mathrm{XX}$, not applicable]

\begin{tabular}{cccccc}
\hline Model & $\begin{array}{c}\text { Regres- } \\
\text { sion } \\
\text { constant }\end{array}$ & $\sigma_{\delta}^{2}$ & ASEV & AVP $_{\text {new }}$ & $\begin{array}{c}\text { Pseudo- } R_{\delta}^{2} \\
\text { (percent) }\end{array}$ \\
\hline $\begin{array}{c}\text { Skewness } \\
\text { coefficient }\end{array}$ & 0.37 & 0.13 & 0.013 & 0.14 & 0 \\
$\begin{array}{c}\text { Standard } \\
\text { deviation }\end{array}$ & 0.11 & 0.03 & $\mathrm{XX}$ & $\mathrm{XX}$ & $\mathrm{XX}$ \\
\hline
\end{tabular}

in a gain in model precision. The constant model provides the best estimate of regional skew for New England.

The posterior mean of the constant model error variance $\left(\sigma_{\delta}^{2}\right)$ is 0.13 (table 2). The average sampling error variance of the constant model was 0.013 , which represents the average error in the regional skew as measured in the at-site skew at streamgages used in the analysis. The average variance of prediction at a new streamgage $\left(A V P_{n e w}\right)$ corresponds to the $M S E$ (Interagency Advisory Committee on Water Data, 1982) used to describe the precision of the generalized skew. The constant model has an $A V P_{\text {new }}$ equal to 0.14 , which corresponds to an effective record length of 56 years. An $A V P_{\text {new }}$ of 0.14 is a marked improvement compared with the average variance of prediction shown in the national skew map of B17B, where the reported MSE of 0.302 has a corresponding effective record length of only 17 years. Thus, the new regional model has more than three times the information content (as measured by effective record length) of that calculated for the map of B17B.

\section{Bayesian Regression Diagnostics}

To determine if a model is a good representation of the data and which regression parameters, if any, should be included in a regression model, diagnostic statistics have been developed to evaluate how well a model fits a regional hydrologic dataset (Griffis, 2006; Gruber and Stedinger, 2008). In a regional skew study, possible explanatory variables are evaluated to provide a region with the most accurate skew prediction while keeping the model as simple as possible. This section details the diagnostic statistics for a B-WLS/B-GLS analysis for the New England regional skew study.

A pseudoanalysis of variance (pseudo-ANOVA) table contains regression diagnostics and goodness of fit statistics (table 3). In particular, these statistics describe how much of the variation in the observations can be attributed to the regional model and how much of the residual variation can be attributed to model error and sampling error. Difficulties arise in determining these quantities. The model errors cannot be resolved because the values of the sampling error $\left(\eta_{i}\right)$ for each streamgage $i$ are not known. However, the sum of the squares of the sampling error $\eta_{i}$ can be described by the mean value of the sampling errors, $\sum_{i=1}^{n} \operatorname{Var}\left[\hat{\gamma}_{i}\right]$ where there are $n$ equations

Table 3. Pseudoanalysis of variance for the New England regional skew constant model.

[ $n$, number of streamgages; $k$, number of basin parameters]

\begin{tabular}{|c|c|c|c|c|}
\hline \multirow{2}{*}{ Source } & \multicolumn{2}{|c|}{ Degrees of freedom } & \multirow{2}{*}{ Equations } & \multirow{2}{*}{ Sum of squares } \\
\hline & Formula & Value & & \\
\hline Model & $k$ & 0 & $n\left[\sigma_{\delta}^{2}(0)-\sigma_{\delta}^{2}(k)\right]$ & 0 \\
\hline Model error & $n-k-1$ & 107 & $n\left[\sigma_{\delta}^{2}(k)\right]$ & 20 \\
\hline Sampling error & $n$ & 108 & $\sum_{i=1}^{n} \operatorname{Var}\left(\hat{\gamma}_{i}\right)$ & 21 \\
\hline Total & $2 n-1$ & 215 & $n\left[\sigma_{\delta}^{2}(k)\right]+\sum_{i=1}^{n} \operatorname{Var}(\hat{\gamma}$ & 41 \\
\hline$E V R=\frac{\sum_{i=1}^{n} \operatorname{Var}\left(\hat{\gamma}_{i}\right)}{n\left[\sigma_{\delta}^{2}(k)\right]}$ & & & & 1.0 \\
\hline$M B V^{*}=\frac{\operatorname{Var}\left[b_{0}^{W L S} \mid G L S \text { analysis }\right.}{\operatorname{Var}\left[b_{0}^{W L S} \mid W L S \text { analysis }\right.}$ & $\frac{w^{T} \Lambda w}{w^{T} v}$ & & $\begin{array}{c}\text { where } w_{i}=\frac{1}{\Lambda_{i i}} \text { and } \\
\quad \mathrm{v}=|\mathrm{n} \times 1|\end{array}$ & 7.8 \\
\hline$R_{\delta}^{2}=1-\frac{\sigma_{\delta}^{2}(k)}{\sigma_{\delta}^{2}(0)}$ & & & & 0 percent \\
\hline
\end{tabular}


(equal to the number of streamgages in the study) and the total variation due to the model error $(\delta)$ for a model with $k$ parameters has a mean equal to $n \sigma_{\delta}^{2}(k)$.

For a model with no explanatory parameters $\left(\gamma_{i}\right)$ other than the mean (as was found by the constant model in this study), the estimated model error variance $\left(\sigma_{\delta}^{2}(0)\right)$ describes all the variation in $\gamma_{i}=\mu+\delta_{i}$, where $\mu$ is the mean of the estimated at-site skews and $\delta_{i}$ is the model error for each streamgage $i$. Thus, the total expected variation in the sum of squares due to $\delta_{i}$ and $\eta_{i}$ is as follows:

$$
\eta_{i}=\hat{\gamma}_{i}-\gamma_{i}=\sigma_{\delta}^{2}(0)+\sum_{i=1}^{n} \operatorname{Var}\left(\hat{\gamma}_{i}\right) .
$$

For a nonconstant regional model, the expected sum of squares for $n$ streamgages attributed with $k$ parameters equals $n\left[\sigma_{\delta}^{2}(0)-\sigma_{\delta}^{2}(k)\right]$ because the sum of the model error variance $n \sigma_{\delta}^{2}(k)$ and the variance explained by the model must equal $n \sigma_{\delta}^{2}(0)$. This division of the variation in the observations is referred to as a pseudo-ANOVA because the contributions of the three sources of error are estimated or constructed rather than being determined from the computed residual errors and the observed model predictions, while also ignoring the effect of correlation among the sampling errors.

The error variance ratio $(E V R)$ is a diagnostic value used to evaluate if a simple OLS regression is sufficient or if a more sophisticated WLS or GLS analysis is appropriate. The EVR is the ratio of the average sampling error variance to the model error variance. An $E V R$ greater than 0.20 generally indicates that the sampling variance is not negligible when compared to the model error variance, suggesting the need for a WLS or GLS regression analysis. The EVR is calculated as follows:

$$
E V R=\frac{S S(\text { sampling error })}{S S(\text { model error })}=\frac{\sum_{i=1}^{n} \operatorname{Var}\left(\hat{\gamma}_{i}\right)}{n \sigma_{\delta}^{2}(k)},
$$

where $S S$ is the sum of squares.

The misrepresentation of the beta variance $\left(M B V^{*}\right)$ statistic is used to determine whether a WLS regression is sufficient or if a GLS regression is appropriate to determine the precision of the estimated regression parameters (Griffis, 2006; Veilleux, 2011). The $M B V^{*}$ describes the error produced by a WLS regression analysis in its evaluation of the precision of the WLS intercept $\left(b_{0}^{W L S}\right)$, which is the estimator of the constant $\beta_{0}^{W L S}$, because the covariance among the estimated atsite skews $\hat{\gamma}$ generally has its greatest effect on the precision of the constant term (Stedinger and Tasker, 1985). If the $M B V^{*}$ is substantially greater than 1, then a GLS error analysis should be employed. Conversely, a WLS analysis is sufficient for small values of $M B V^{*}$. The $M B V^{*}$ is calculated as,

$$
M B V^{*}=\frac{\operatorname{Var}\left[b_{0}^{W L S} \mid \text { GLS analysis }\right]}{\operatorname{Var}\left[b_{0}^{W L S} \mid W L S \text { analysis }\right]}=\frac{w^{T} \Lambda w}{\sum_{i=1}^{n} w_{i}},
$$

where $w$ is the vector of weights for the WLS analysis.
The pseudo-ANOVA results for the constant model $(k=0)$, along with other model diagnostics, determined for the New England regional skew model are provided in table 3. The constant model does not have any explanatory variables, thus the variation attributed to the model is 0 . The constant model has a sampling error variance greater than its model error variance (table 3); the EVR for the constant model has a value of 1.05 . The sampling variability in the sample skew was greater than the error in the regional model. Thus, an OLS model that neglects sampling error in the at-site skew may not provide a statistically reliable analysis of the data. Given the variation of record lengths among streamgages, a WLS or GLS analysis is needed to evaluate the final precision of the model rather than a simple OLS analysis.

The $M B V^{*}$ for the constant model is equal to 7.8. This is a large value, indicating the cross correlation among the skew estimators has had an effect on the precision with which the regional average skew can be estimated; if a WLS precision analysis were used for the estimated constant parameter in the constant model, then the variance would be underestimated by a factor of 7.8. Thus, a WLS analysis would seriously misrepresent the variance of the constant in the New England regional skew model. Moreover, a WLS model would result in underestimation of the variance of prediction given that the sampling error in both the WLS and GLS models was sufficiently large enough to make an appreciable contribution to the average variance of prediction.

\section{Leverage and Influence}

Leverage and influence diagnostics statistics can be used to identify rogue observations and to effectively address lack-of-fit when estimating skews. Leverage identifies those streamgages in the analysis where the observed values have a large effect on the fitted (or predicted) values (Hoaglin and Welsch, 1978). Generally, leverage considers whether an observation, or explanatory variable, is unusual and thus likely to have a large effect on the estimated regression skews and predictions. Unlike leverage, which highlights points that have the ability or potential to affect the fit of the regression, influence attempts to describe those points that have an unusual effect on the regression analysis (Belsley and others, 1980; Cook and Weisberg, 1982; Tasker and Stedinger, 1989). An influential observation is one with an unusually large residual that has a disproportionate effect on the fitted regression relations.

Influential observations often have high leverage. If $p$ is the number of estimated regression skews ( $p=1$ for a constant model) and $n$ is the sample size (or number of streamgages in the study), then leverage values have a mean of $p / n$ and values greater than $2 p / n$ are generally considered large. Influence values greater than $4 / n$ are typically considered large (Tasker and Stedinger, 1989; Veilleux, 2011; Veilleux and others, 2011). Veilleux and others (2011) and Veilleux (2011) provide 
Table 4. Streamgages with high influence in the New England regional skew constant model.

[High influence is defined as Cook's D values greater than $4 / n$ (or $4 / 153=0.026$ ). Each of the streamgages was assigned a rank from 1 to 153 for each category (pseudorecord length $\left[P_{R L}\right]$, unbiased at-site skew, unbiased mean squared error [MSE] of at-site skew, residual) where a rank of 1 corresponds to the highest positive value in each category. ME, Maine; NH, New Hampshire; MA, Massachusetts; CT, Connecticut]

\begin{tabular}{|c|c|c|c|c|c|c|c|c|c|c|c|c|}
\hline \multirow{2}{*}{$\begin{array}{c}\text { Index } \\
\text { number }\end{array}$} & \multirow{2}{*}{$\begin{array}{c}\text { USGS } \\
\text { streamgage } \\
\text { number }\end{array}$} & \multirow[t]{2}{*}{ State } & \multirow[t]{2}{*}{ Cook's D } & \multirow[t]{2}{*}{ Leverage } & \multicolumn{2}{|c|}{$\begin{array}{c}\text { Pseudo ERL } \\
\text { (years) }\end{array}$} & \multicolumn{2}{|c|}{$\begin{array}{c}\text { Unbiased } \\
\text { (at-site skew) }\end{array}$} & \multicolumn{2}{|c|}{$\begin{array}{l}\text { Unbiased MSE } \\
\text { (at-site skew) }\end{array}$} & \multicolumn{2}{|c|}{ Residual } \\
\hline & & & & & Value & Rank & Value & Rank & Value & Rank & Value & Rank \\
\hline 166 & 1150900 & $\mathrm{NH}$ & 0.120 & 0.0075 & 84 & 22 & 2.1 & 2 & 0.41 & 7 & 1.71 & 2 \\
\hline 115 & 1176000 & MA & 0.087 & 0.0079 & 99 & 11 & 1.7 & 5 & 0.29 & 13 & 1.31 & 5 \\
\hline 110 & 1173500 & MA & 0.042 & 0.0055 & 45 & 124 & 2.0 & 3 & 0.58 & 3 & 1.65 & 3 \\
\hline 62 & 1209700 & $\mathrm{CT}$ & 0.033 & 0.0058 & 49 & 113 & 1.7 & 4 & 0.42 & 6 & 1.35 & 4 \\
\hline 99 & 1162000 & MA & 0.031 & 0.0078 & 94 & 14 & 1.2 & 10 & 0.17 & 43 & 0.81 & 10 \\
\hline 163 & 1142500 & $\mathrm{NH}$ & 0.029 & 0.0092 & 163 & 3 & 1.0 & 19 & 0.09 & 132 & 0.63 & 19 \\
\hline
\end{tabular}

a detailed description of the equations used to determine influence and leverage for a B-WLS/B-GLS analysis.

For the New England regional skew constant model, high influence is defined as influence greater than 0.026 (or $4 p / n=4 / 153$ ) and high leverage is defined as leverage greater than 0.013 (or $2 p / n=(2 \times 1) / 153$ ). No sites in the study had high leverage, and thus the differences in the leverage values for the constant model reflect the variation in record lengths among sites. Nine sites in the study have high influence (table 4) and thus have an unusually large effect on the fitted regression relation. The five sites with the greatest unbiased at-site skew are part of the nine sites with high influence. The most influential streamgage (USGS 01055000, Swift River near Roxbury, Maine), as measured by Cook's distance (Cook, 1977) and the unbiased skew and residual ranks, also has the smallest unbiased at-site skew (that is, the most negative skew) of all streamgages used in the study. Each of the 153 streamgages used in the regional skew study was assigned a rank from 1 to 153 , where a rank of 1 corresponds to the highest positive value in each category.

\section{Summary}

The flood frequency guidelines for the United States recommend fitting a log-Pearson type III distribution to a series of annual flood maximums. This distribution, in the specific case of flood frequency analysis, is described by three moments: the mean, the standard deviation, and the skewness coefficient (or skew) of the logarithms of the flow. The skew is very sensitive to extreme events, such as large floods, because they cause a sample to be highly skewed, or asymmetrical.

The magnitude of annual exceedance probability floods is greatly affected by the skew of the annual peak flows at a streamgage. Thus, the recommended method for estimating streamgage skew is to weight the station skew with a regional skew to better reflect regional and long-term hydrology.

In order to determine the at-site skew for each streamgage in the regional skew analysis, an expected moments algorithm with multiple Grubbs-Beck censoring of potentially influential low floods was used to compute moments of the logarithms for the log-Pearson type III distribution. The Bayesian weighted least squares/Bayesian generalized least squares regression method was used to develop a regional skew model for New England.

The study area for the New England regional skew analysis consists of the entire States of Connecticut, Maine, New Hampshire, Rhode Island, Vermont, most of Massachusetts (excluding Cape Cod and the islands), and the easternmost part of New York. The region spans about 500 miles from southeastern Connecticut to northern Maine. A total of 186 streamgages were evaluated for use in the analysis. Streamgage basin characteristics were obtained from the Geospatial Attributes of Gages for Evaluating Streamflow, version II (GAGES II) database. Various basin characteristics were considered as possible explanatory variables in the Bayesian weighted least squares/Bayesian generalized least squares regression analysis for regional skew. All available basin characteristics were evaluated, but none produced a pseudocoefficient of determination greater than 13 percent, indicating that basin characteristics did not help in explaining the variation in at-site skews in New England. Based on the results of these analyses, a regional skew constant model was chosen. The constant model yielded a regional skew of 0.37 , a model error variance of 0.13 , and an average variance of prediction at a new site of 0.14 . An average variance of prediction of 0.14 is a marked improvement from the skew from the nationally recommended flood frequency guidelines, whose reported mean squared error is 0.302 . 


\section{References Cited}

Beard, L.R., 1974, Flood flow frequency techniques-A report: University of Texas at Austin, [variously paged].

Belsley, D.A., Kuh, E., and Welsch, R.E., 1980, Detecting influential observations and outliers, chap. 2 of Regression diagnostics-Identifying influential data and sources of collinearity: John Wiley \& Sons, Inc., p. 6-84.

Cember, R.P., and Wilks, D.S., 1993, Climatological atlas of snowfall and snow depth for the northeastern United States and southeastern Canada: Northeast Regional Climate Center Research Publication RR 93-1, 216 p.

Cohn, T.A., England, J.F., Berenbrock, C.E., Mason, R.R., Stedinger, J.R., and Lamontagne, J.R., 2013, A generalized Grubbs-Beck test statistic for detecting multiple potentially influential low outliers in flood series: Water Resources Research, v. 49, no. 8, p. 5047-5058. [Also available at https://doi.org/10.1002/wrcr.20392.

Cohn, T.A., Lane, W.L., and Baier, W.G., 1997, An algorithm, for computing moments-based flood quantile estimates when historical flood information is available: Water Resources Research, v. 33, no. 9, p. 2089-2096. [Also available at https://doi.org/10.1029/97WR01640.]

Cohn, T.A., Lane, W.L., and Stedinger, J.R., 2001, Confidence intervals for expected moments algorithm flood quantile estimates: Water Resources Research, v. 37, no. 6, p. 1695-1706. [Also available at https://doi.org/10.1029/2001WR900016.]

Cook, R.D., 1977, Detection of influential observations in linear regression: Technometrics, v. 19, no. 1, p. 15-18. [Also available at https://doi.org/10.2307/1268249.]

Cook, R.D., and Weisberg, S., 1982, Residuals and influence in regression: New York City, Chapman and Hall, 230 p.

Denny, C.S., 1982, Geomorphology of New England: U.S. Geological Survey Professional Paper 1208, 18 p. [Also available at https://doi.org/10.3133/pp1208.]

Eash, D.A., Barnes, K.K., and Veilleux, A.G., 2013, Methods for estimating annual exceedance-probability discharges for streams in Iowa, based on data through water year 2010: U.S. Geological Survey Scientific Investigations Report 2013-5086, 63 p. [Also available at https://doi.org/10.3133/ sir20135086.]

Falcone, J.A., 2011, GAGES-II-Geospatial attributes of gages for evaluating streamflow: U.S. Geological Survey dataset, accessed October 23, 2016, at https://doi.org/10.3133/70046617.
Feaster, T.D., Gotvald, A.J., and Weaver, J.C., 2009, Magnitude and frequency of rural floods in the southeastern United States, 2006-Volume 3, South Carolina: U.S. Geological Survey Scientific Investigations Report 20095156, 226 p. [Also available at https://doi.org/10.3133/ sir20095156.]

Gotvald, A.J., Barth, N.A., Veilleux, A.G., and Parrett, C., 2012, Methods for determining magnitude and frequency of floods in California, based on data through water year 2006: U.S. Geological Survey Scientific Investigations Report 2012-5113, 38 p., 1 pl., data, accessed September 12, 2016, at https://doi.org/10.3133/sir20125113.

Gotvald, A.J., Feaster, T.D., and Weaver, J.C., 2009, Magnitude and frequency of rural floods in the southeastern United States, 2006-Volume 1, Georgia: U.S. Geological Survey Scientific Investigations Report 2009-5043, 120 p. [Also available at https://doi.org/10.3133/sir20095043.]

Griffis, V.W., 2006, Flood frequency analysis-Bulletin 17, regional information, and climate change: Cornell University Ph.D. dissertation, $482 \mathrm{p}$.

Griffis, V.W., and Stedinger, J.R., 2007a, Log-Pearson type 3 distribution and its application in flood frequency analysis. II-Parameter estimation methods: Journal of Hydrologic Engineering, v. 12, no. 5, p. 492-500. [Also available at https://doi.org/10.1061/(ASCE)1084-0699(2007)12:5(492).]

Griffis, V.W., and Stedinger, J.R., 2007b, The use of GLS regression in regional hydrologic analyses: Journal of Hydrology, v. 344, nos. 1-2, p. 82-95. [Also available at https://doi.org/10.1016/j.jhydrol.2007.06.023.]

Griffis, V.W., and Stedinger, J.R., 2009a, Closure to "LogPearson type 3 distribution and its application in flood frequency analysis. II-Parameter estimation methods": Journal of Hydrologic Engineering, v. 14, no. 2, p. 209-212. [Also available at https://doi.org/10.1061/(ASCE)10840699(2009)14:2(209).]

Griffis, V.W., and Stedinger, J.R., 2009b, Log-Pearson type 3 distribution and its application in flood frequency analysis. III-Sample skew and weighted skew estimators: Journal of Hydrology, v. 14, no. 2, p. 121-130. [Also available at https://doi.org/10.1061/(ASCE)1084-0699(2009)14:2(121).]

Griffis, V.W., Stedinger, J.R., and Cohn, T.A., 2004, Log Pearson type 3 quantile estimators with regional skew information and low outlier adjustments: Water Resources Research, v. 40, no. 7, article W07503, 17 p., accessed June 23, 2016, at https://doi.org/10.1029/2003WR002697.

Grubbs, F.E., and Beck, G., 1972, Extension of sample sizes and percentage points for significance test of outlying observations: Technometrics, v. 14, no. 4, p. 847-854. [Also available at https://doi.org/10.1080/00401706.1972.1 0488981.] 
Gruber, A.M., Reis, D.S., Jr., and Stedinger, J.R., 2007, Models of regional skew based on Bayesian GLS regression, in Kabbes, K.C., ed., World Environmental and Water Resources Congress-Restoring our natural habitat: American Society of Civil Engineers, paper 40927-3285, 10 p.

Gruber, A.M., and Stedinger, J.R., 2008, Models of LP3 regional skew, data selection and Bayesian GLS regression, in Babcock, R.W., Jr., and Walton, Raymond, eds., World Environmental and Water Resources Congress: American Society of Civil Engineers, paper 596, 10 p.

Hardison, C.H., 1975, Generalized skew coefficients of annual floods in the United States and their application: Water Resources Research, v. 11, no. 6, p. 851-854. [Also available at https://doi.org/10.1029/WR010i004p00745.]

Hoaglin, D.C., and Welsch, R.E., 1978, The hat matrix in regression and ANOVA: The American Statistician, v. 32, no. 1, p. 17-22. [Also available at https://doi.org/10.1080/00031305.1978.10479237.]

Interagency Advisory Committee on Water Data, 1982, Guidelines for determining flood flow frequency: U.S. Geological Survey Bulletin 17B, 28 p. [Also available at https://water.usgs.gov/osw/bulletin17b/dl_flow.pdf.]

Lamontagne, J.R., Stedinger, J.R., Berenbrock, C., Veilleux, A.G., Ferris, J.C., and Knifong, D.L., 2012, Development of regional skews for selected flood durations for the Central Valley region, California, based on data through water year 2008: U.S. Geological Survey Scientific Investigations Report 2012-5130, 60 p., appendix, accessed August 24, 2014, at https://doi.org/10.3133/sir20125130.

Martins, E.S., and Stedinger, J.R., 2002, Cross-correlation among estimators of shape: Water Resources Research, v. 38 , no. 11 , article 1252 , p. 34-1-34-7, accessed July 8, 2016, at https://doi.org/10.1029/2002WR001589.

McCuen, R.H., 1979, Map skew: Journal of the Water Resources Planning and Management Division, v. 105, no. WR2, p. 265-277.

McCuen, R.H., 2001, Generalized flood skew—Map versus watershed skew: Journal of Hydrologic Engineering, v. 6, no. 4, p. 293-299. [Also available at http://dx.doi.org/10.1061/(ASCE)10840699(2001)6:4(293).]

National Oceanic and Atmospheric Administration, 2013, Regional climate trends and scenarios for the U.S. national climate assessment-Part 1. Climate of the northeast U.S.: National Oceanic and Atmospheric Administration Technical Report NESDIS 142-1, 79 p., accessed June 23, 2016, at https://scenarios.globalchange.gov/sites/default/files/ NOAA_NESDIS_Tech_Report_142-1-Climate_of_the Northeast_U.S_1.pdf.
National Oceanic and Atmospheric Administration, [undated], Historical hurricane tracks: National Oceanic and Atmospheric Administration Web mapping service, accessed July 23, 2016, at http://www.csc.noaa.gov/hurricanes/. [Moved to https://oceanservice.noaa.gov/news/historical-hurricanes/ at time of publication.]

Northeast Regional Climate Center, 2014, Northeast climate normal maps 1981-2010: Northeast Regional Climate Center Web page, accessed April 16, 2014, at http://www.nrcc.cornell.edu/page_northeast.html. [Moved to https://www.ncdc.noaa.gov/data-access/ land-based-station-data/land-based-datasets/climatenormals/1981-2010-normals-data at time of publication.]

Paretti, N.V., Kennedy, J.R., Turney, L.A., and Veilleux, A.G., 2014, Methods for estimating magnitude and frequency of floods in Arizona, developed with unregulated and rural peak-flow data through water year 2010: U.S. Geological Survey Scientific Investigations Report 2014-5211, 61 p., accessed June 24, 2015, at https://doi.org/10.3133/ $\operatorname{sir} 20145211$.

Parrett, C., Veilleux, A., Stedinger, J.R., Barth, N.A., Knifong, D.L., and Ferris, J.C., 2011, Regional skew for California, and flood frequency for selected sites in the SacramentoSan Joaquin River Basin, based on data through water year 2006: U.S. Geological Survey Scientific Investigations Report 2010-5260, 94 p., data, accessed June 24, 2014, at https://doi.org/10.3133/sir20105260.

Reis, D.S., Jr., Stedinger, J.R., and Martins, E.S., 2005, Bayesian generalized least squares regression with application to the log Pearson type III regional skew estimation: Water Resources Research, v. 41, no. 10, paper W10419, 14 p., accessed February 12, 2016, at https://doi.org/10.1029/2004WR003445.

Southard, R.E., and Veilleux, A.G., 2014, Methods for estimating annual exceedance-probability discharges and largest recorded floods for unregulated streams in rural Missouri: U.S. Geological Survey Scientific Investigations Report 2014-5165, 39 p. [Also available at https://doi.org/10.3133/ sir20145165.]

Stedinger, J.R., and Tasker, G.D., 1985, Regional hydrologic analysis - 1. Ordinary, weighted, and generalized least squares compared: Water Resources Research, v. 21, no. 9, p. 1421-1432. [Also available at https://doi.org/10.1029/ WR021i009p01421.]

Stedinger, J.R., and Cohn, T.A., 1986, Flood frequency analysis with historical and paleoflood information: Water Resources Research, v. 22, no. 5, p. 785-793. [Also available at https://doi.org/10.1029/WR022i005p00785.] 
Stedinger, J.R., and Griffis, V.W., 2008, Flood frequency analysis in the United States-Time to update: Journal of Hydrologic Engineering, v. 13, no. 4, p. 199-204. [Also available at https://doi.org/10.1061/(ASCE)10840699(2008)13:4(199).]

Tasker, G.D., 1978, Flood frequency analysis with a generalized skew coefficient: Water Resources Research, v. 14, no. 2, p. 373-376. [Also available at https://doi.org/10.1029/ WR014i002p00373.]

Tasker, G.D., and Stedinger, J.R., 1986, Regional skew with weighted LS regression: Journal of Water Resources Planning and Management, v. 112, no. 2, p. 225-237. [Also available at https://doi.org/10.1061/(ASCE)07339496(1986)112:2(225).]

Tasker, G.D., and Stedinger, J.R., 1989, An operational GLS model for hydrologic regression: Journal of Hydrology, v. 111, nos. 1-4, p. 361-375. [Also available at https://doi.org/10.1016/0022-1694(89)90268-0.]

U.S. Environmental Protection Agency, 2012, ORD/USEPA Ecoregions_Level_III_and_IV (MapServer): U.S. Environmental Protection Agency map server, accessed July 23, 2014, at http://geodata.epa.gov/ArcGIS/rest/services/ORD/ USEPA_Ecoregions_Level_III_and_IV/MapServer.

U.S. Environmental Protection Agency, 2013, Level III ecoregions of the continental United States: U.S. Environmental Protection Agency map, scale 1:7,500,000, accessed March 24, 2014, at https://www.epa.gov/eco-research/level-iii-andiv-ecoregions-continental-united-states.

U.S. Geological Survey, 2014a, Peak streamflow for the nation: U.S. Geological Survey National Water Information System Web database, accessed June 13, 2014, at https://doi.org/10.5066/F7P55KJN. [Specific information directly accessible at https://nwis.waterdata.usgs.gov/nwis/ peak.]

U.S. Geological Survey, 2014b, PeakFQ — Flood frequency analysis based on bulletin 17B and recommendations of the Advisory Committee on Water Information (ACWI) Subcommittee on Hydrology (SOH) Hydrologic Frequency Analysis Work Group (HFAWG): U.S. Geological Survey software page, accessed June 13, 2014, at https://water.usgs.gov/software/PeakFQ/.
Veilleux, A.G., 2009, Bayesian GLS regression for regionalization of hydrologic statistics, floods and bulletin 17 skew: Ithaca, N.Y., Cornell University M.S. thesis, 155 p. [Also available at https://hdl.handle.net/1813/13819.]

Veilleux, A.G., 2011, Bayesian GLS regression, leverage and influence for regionalization of hydrologic statistics: Ithaca, N.Y., Cornell University Ph.D. dissertation, 184 p. [Also available at https://hdl.handle.net/1813/30607.]

Veilleux, A.G., Cohn, T.A., Flynn, K.M., Mason, R.R., Jr., and Hummel, P.R., 2014, Estimating magnitude and frequency of floods using the PeakFQ 7.0 program: U.S. Geological Survey Fact Sheet 2013-3108, 2 p., accessed October 23, 2016, at https://doi.org/10.3133/fs20133108.

Veilleux, A.G., Stedinger, J.R., and Eash, D.A., 2012, Bayesian WLS/GLS regression for regional skewness analysis for regions with large crest stage gage networks, in Loucks, E.D., ed., World Environmental and Water Resources Congress - Crossing boundaries: American Society of Civil Engineers, p. 2253-2263.

Veilleux, A.G., Stedinger, J.R., and Lamontagne, J.R., 2011, Bayesian WLS/GLS regression for regional skewness analysis for regions with large cross-correlations among flood flows, in Beighley, R.E., II, and Killgore, M.W., eds., World Environmental and Water Resources CongressBearing knowledge for sustainability: American Society of Civil Engineers, p. 3103-3112. [Also available at https://doi.org/10.1061/41173(414)324.]

Wagner, D.M., and Veilleux, A.G., 2019, Peak-flow files and PeakFQ output files for U.S. Geological Survey streamgages in the New England region that were used in regional skew analysis: U.S. Geological Survey data release, https://doi.org/10.5066/P9MC98OM.

Weaver, J.C., Feaster, T.D., and Gotvald, A.J., 2009, Magnitude and frequency of rural floods in the southeastern United States, 2006-Volume 2, North Carolina: U.S. Geological Survey Scientific Investigations Report 2009-5158, 113 p., data, accessed June 23, 2016, at https://doi.org/10.3133/sir20095158. 
Table 1. Streamgages in Connecticut, Maine, Massachusetts, New Hampshire, Rhode Island, Vermont, and easternmost New York used in the New England regional skew analysis.

[USGS, U.S. Geological Survey; EMA, expected moments algorithm; MSE, mean squared error; No-R, streamgage not used in regional skew analysis because of redundancy; No-P, streamgage not used in regional skew analysis because the pseudorecord length $\left(\mathrm{P}_{R L}\right)$ was less than 30 years]

\begin{tabular}{|c|c|c|c|c|c|c|}
\hline \multirow{2}{*}{$\begin{array}{l}\text { Regional skew } \\
\text { index number }\end{array}$} & \multirow{2}{*}{$\begin{array}{c}\text { USGS } \\
\text { streamgage } \\
\text { number }\end{array}$} & \multirow{2}{*}{$\begin{array}{l}\text { State where } \\
\text { streamgage } \\
\text { is located }\end{array}$} & \multirow[b]{2}{*}{$P_{R L}$} & \multicolumn{2}{|c|}{ EMA analysis } & \multirow{2}{*}{$\begin{array}{l}\text { Used in regional } \\
\text { skew model }\end{array}$} \\
\hline & & & & $\begin{array}{c}\text { Skew, } \\
\text { in log units }\end{array}$ & $\begin{array}{l}\text { MSE of skew, } \\
\text { in log units }\end{array}$ & \\
\hline 1 & 01011000 & Maine & 80 & -0.09 & 0.07 & Yes \\
\hline 2 & 01013500 & Maine & 87 & -0.10 & 0.05 & Yes \\
\hline 3 & 01015800 & Maine & 54 & -0.44 & 0.13 & Yes \\
\hline 4 & 01016500 & Maine & 32 & 0.08 & 0.16 & Yes \\
\hline 5 & 01018000 & Maine & 50 & -0.11 & 0.80 & Yes \\
\hline 6 & 01022500 & Maine & 64 & -0.01 & 0.08 & Yes \\
\hline 7 & 01023000 & Maine & 60 & 0.18 & 0.08 & Yes \\
\hline 8 & 01030500 & Maine & 109 & 0.13 & 0.06 & Yes \\
\hline 9 & 01031500 & Maine & 117 & -0.01 & 0.05 & Yes \\
\hline 10 & 01033500 & Maine & 65 & 0.29 & 0.10 & Yes \\
\hline 11 & 01035000 & Maine & 64 & 0.32 & 0.10 & Yes \\
\hline 12 & 01038000 & Maine & 73 & 0.57 & 0.11 & Yes \\
\hline 13 & 01046000 & Maine & 41 & 0.27 & 0.14 & Yes \\
\hline 14 & 01047000 & Maine & 86 & -0.14 & 0.07 & Yes \\
\hline 15 & 01048000 & Maine & 107 & -0.28 & 0.06 & Yes \\
\hline 16 & 01049000 & Maine & 83 & 0.12 & 0.07 & Yes \\
\hline 17 & 01054200 & Maine & 51 & -0.51 & 0.14 & Yes \\
\hline 18 & 01054300 & Maine & 30 & -0.56 & 0.15 & Yes \\
\hline 19 & 01055000 & Maine & 82 & -1.41 & 0.24 & Yes \\
\hline 20 & 01055500 & Maine & 92 & 0.21 & 0.06 & Yes \\
\hline 21 & 01057000 & Maine & 104 & -0.18 & 0.05 & Yes \\
\hline 22 & 01058500 & Maine & 48 & 0.91 & 0.19 & Yes \\
\hline 23 & 01059800 & Maine & 21 & -0.74 & 0.21 & No-P \\
\hline 24 & 01060000 & Maine & 55 & 0.06 & 0.10 & Yes \\
\hline 25 & 01066000 & Maine & 222 & -0.03 & 0.03 & Yes \\
\hline 26 & 01066500 & Maine & 70 & 0.27 & 0.08 & Yes \\
\hline 27 & 01118300 & Connecticut & 53 & 0.11 & 0.10 & Yes \\
\hline 28 & 01119500 & Connecticut & 80 & 0.65 & 0.11 & Yes \\
\hline 29 & 01120000 & Connecticut & 59 & 0.22 & 0.10 & Yes \\
\hline 30 & 01120500 & Connecticut & 31 & 0.29 & 0.19 & Yes \\
\hline 31 & 01121000 & Connecticut & 71 & 0.56 & 0.11 & Yes \\
\hline 32 & 01123000 & Connecticut & 60 & -0.17 & 0.10 & Yes \\
\hline 33 & 01124000 & Connecticut & 42 & 2.05 & 0.79 & Yes \\
\hline 34 & 01126000 & Connecticut & 47 & 0.30 & 0.13 & Yes \\
\hline 35 & 01126500 & Connecticut & 50 & 0.26 & 0.12 & Yes \\
\hline 36 & 01127500 & Connecticut & 81 & 0.24 & 0.08 & Yes \\
\hline 37 & 01184100 & Connecticut & 52 & 0.14 & 0.11 & Yes \\
\hline 38 & 01184490 & Connecticut & 45 & 0.21 & 0.13 & Yes \\
\hline 39 & 01184500 & Connecticut & 56 & 1.08 & 0.21 & No-R \\
\hline 40 & 01187300 & Connecticut & 61 & 0.06 & 0.09 & Yes \\
\hline
\end{tabular}


Table 1. Streamgages in Connecticut, Maine, Massachusetts, New Hampshire, Rhode Island, Vermont, and easternmost New York used in the New England regional skew analysis.-Continued

[USGS, U.S. Geological Survey; EMA, expected moments algorithm; MSE, mean squared error; No-R, streamgage not used in regional skew analysis because of redundancy; No-P, streamgage not used in regional skew analysis because the pseudorecord length $\left(\mathrm{P}_{R L}\right)$ was less than 30 years]

\begin{tabular}{|c|c|c|c|c|c|c|}
\hline \multirow{2}{*}{$\begin{array}{l}\text { Regional skew } \\
\text { index number }\end{array}$} & \multirow{2}{*}{$\begin{array}{c}\text { USGS } \\
\text { streamgage } \\
\text { number }\end{array}$} & \multirow{2}{*}{$\begin{array}{l}\text { State where } \\
\text { streamgage } \\
\text { is located }\end{array}$} & \multirow[b]{2}{*}{$P_{R L}$} & \multicolumn{2}{|c|}{ EMA analysis } & \multirow{2}{*}{$\begin{array}{l}\text { Used in regional } \\
\text { skew model }\end{array}$} \\
\hline & & & & $\begin{array}{c}\text { Skew, } \\
\text { in log units }\end{array}$ & $\begin{array}{l}\text { MSE of skew, } \\
\text { in log units }\end{array}$ & \\
\hline 41 & 01187800 & Connecticut & 30 & 0.65 & 0.23 & Yes \\
\hline 42 & 01188000 & Connecticut & 80 & 0.02 & 0.07 & Yes \\
\hline 43 & 01189000 & Connecticut & 75 & 0.42 & 0.09 & Yes \\
\hline 44 & 01190500 & Connecticut & 46 & 0.21 & 0.13 & Yes \\
\hline 45 & 01191000 & Connecticut & 27 & 1.43 & 0.46 & No-P \\
\hline 46 & 01192500 & Connecticut & 85 & 0.08 & 0.07 & Yes \\
\hline 47 & 01192883 & Connecticut & 50 & -0.36 & 0.13 & Yes \\
\hline 48 & 01193500 & Connecticut & 83 & 0.55 & 0.10 & Yes \\
\hline 49 & 01194000 & Connecticut & 51 & 0.49 & 0.14 & Yes \\
\hline 50 & 01194500 & Connecticut & 55 & 1.34 & 0.30 & No-R \\
\hline 51 & 01195100 & Connecticut & 30 & 1.29 & 0.38 & Yes \\
\hline 52 & 01196500 & Connecticut & 81 & -0.12 & 0.07 & Yes \\
\hline 53 & 01196620 & Connecticut & 35 & 0.33 & 0.17 & Yes \\
\hline 54 & 01199000 & Connecticut & 99 & 0.50 & 0.08 & No-R \\
\hline 55 & 01199050 & Connecticut & 50 & 0.15 & 0.11 & Yes \\
\hline 56 & 01200000 & Connecticut & 79 & 0.37 & 0.09 & Yes \\
\hline 57 & 01203600 & Connecticut & 26 & -0.32 & 0.21 & No-P \\
\hline 58 & 01204000 & Connecticut & 79 & 0.68 & 0.11 & Yes \\
\hline 59 & 01208925 & Connecticut & 39 & -0.07 & 0.13 & Yes \\
\hline 60 & 01208950 & Connecticut & 52 & 0.74 & 0.16 & Yes \\
\hline 61 & 01208990 & Connecticut & 50 & 0.05 & 0.11 & Yes \\
\hline 62 & 01209700 & Connecticut & 49 & 1.53 & 0.34 & Yes \\
\hline 63 & 01094500 & Massachusetts & 76 & 0.37 & 0.09 & Yes \\
\hline 64 & 01096000 & Massachusetts & 62 & -0.14 & 0.09 & Yes \\
\hline 65 & 01097000 & Massachusetts & 70 & 0.12 & 0.08 & Yes \\
\hline 66 & 01097300 & Massachusetts & 48 & -0.13 & 0.12 & Yes \\
\hline 67 & 01099500 & Massachusetts & 74 & -0.21 & 0.08 & No-R \\
\hline 68 & 01100600 & Massachusetts & 48 & 0.24 & 0.12 & Yes \\
\hline 69 & 01101000 & Massachusetts & 66 & 0.47 & 0.11 & Yes \\
\hline 70 & 01102000 & Massachusetts & 81 & 0.12 & 0.07 & Yes \\
\hline 71 & 01102500 & Massachusetts & 72 & 0.37 & 0.09 & Yes \\
\hline 72 & 01104500 & Massachusetts & 80 & 0.26 & 0.08 & Yes \\
\hline 73 & 01105000 & Massachusetts & 72 & 0.53 & 0.11 & No-R \\
\hline 74 & 01105500 & Massachusetts & 59 & 0.61 & 0.13 & Yes \\
\hline 75 & 01105600 & Massachusetts & 45 & -0.14 & 0.12 & Yes \\
\hline 76 & 01105730 & Massachusetts & 45 & 0.12 & 0.12 & Yes \\
\hline 77 & 01105870 & Massachusetts & 45 & -0.05 & 0.12 & Yes \\
\hline 78 & 01106000 & Rhode Island & 38 & -0.57 & 0.19 & Yes \\
\hline 79 & 01108000 & Massachusetts & 65 & 0.05 & 0.08 & Yes \\
\hline 80 & 01109000 & Massachusetts & 86 & 0.27 & 0.08 & Yes \\
\hline
\end{tabular}


Table 1. Streamgages in Connecticut, Maine, Massachusetts, New Hampshire, Rhode Island, Vermont, and easternmost New York used in the New England regional skew analysis.-Continued

[USGS, U.S. Geological Survey; EMA, expected moments algorithm; MSE, mean squared error; No-R, streamgage not used in regional skew analysis because of redundancy; No-P, streamgage not used in regional skew analysis because the pseudorecord length $\left(\mathrm{P}_{R L}\right)$ was less than 30 years]

\begin{tabular}{|c|c|c|c|c|c|c|}
\hline \multirow{2}{*}{$\begin{array}{l}\text { Regional skew } \\
\text { index number }\end{array}$} & \multirow{2}{*}{$\begin{array}{c}\text { USGS } \\
\text { streamgage } \\
\text { number }\end{array}$} & \multirow{2}{*}{$\begin{array}{l}\text { State where } \\
\text { streamgage } \\
\text { is located }\end{array}$} & \multirow[b]{2}{*}{$P_{R L}$} & \multicolumn{2}{|c|}{ EMA analysis } & \multirow{2}{*}{$\begin{array}{l}\text { Used in regional } \\
\text { skew model }\end{array}$} \\
\hline & & & & $\begin{array}{c}\text { Skew, } \\
\text { in log units }\end{array}$ & $\begin{array}{l}\text { MSE of skew, } \\
\text { in log units }\end{array}$ & \\
\hline 81 & 01109060 & Massachusetts & 45 & -0.39 & 0.14 & No-R \\
\hline 82 & 01109070 & Massachusetts & 45 & 0.05 & 0.12 & Yes \\
\hline 83 & 01109500 & Massachusetts & 55 & 0.60 & 0.14 & Yes \\
\hline 84 & 01110000 & Massachusetts & 72 & 0.01 & 0.07 & Yes \\
\hline 85 & 01110500 & Massachusetts & 47 & 0.41 & 0.14 & No-R \\
\hline 86 & 01111300 & Rhode Island & 45 & 0.24 & 0.13 & No-R \\
\hline 87 & 01111500 & Rhode Island & 69 & 0.18 & 0.09 & Yes \\
\hline 88 & 01112500 & Rhode Island & 83 & 0.38 & 0.08 & No-R \\
\hline 89 & 01114500 & Rhode Island & 71 & -0.14 & 0.08 & Yes \\
\hline 90 & 01116000 & Rhode Island & 71 & 0.60 & 0.11 & Yes \\
\hline 91 & 01117000 & Rhode Island & 71 & 0.96 & 0.15 & Yes \\
\hline 92 & 01117350 & Rhode Island & 38 & 0.92 & 0.22 & Yes \\
\hline 93 & 01117420 & Rhode Island & 36 & 0.52 & 0.18 & No-R \\
\hline 94 & 01117468 & Rhode Island & 37 & 0.84 & 0.21 & Yes \\
\hline 95 & 01117500 & Rhode Island & 71 & 0.96 & 0.15 & Yes \\
\hline 96 & 01118000 & Rhode Island & 70 & 1.04 & 0.17 & Yes \\
\hline 97 & 01118500 & Rhode Island & 72 & 0.96 & 0.15 & No-R \\
\hline 98 & 01161500 & Massachusetts & 66 & 1.28 & 0.23 & No-R \\
\hline 99 & 01162000 & Massachusetts & 94 & 1.11 & 0.15 & Yes \\
\hline 100 & 01162500 & Massachusetts & 94 & 0.57 & 0.09 & Yes \\
\hline 101 & 01163200 & Massachusetts & 47 & -0.02 & 0.11 & Yes \\
\hline 102 & 01165000 & Massachusetts & 32 & 1.17 & 0.32 & Yes \\
\hline 103 & 01165500 & Massachusetts & 66 & 0.32 & 0.10 & Yes \\
\hline 104 & 01168500 & Massachusetts & 98 & 0.38 & 0.07 & No-R \\
\hline 105 & 01169000 & Massachusetts & 72 & 0.84 & 0.13 & Yes \\
\hline 106 & 01169900 & Massachusetts & 45 & 0.85 & 0.19 & Yes \\
\hline 107 & 01170100 & Massachusetts & 44 & 1.21 & 0.28 & Yes \\
\hline 108 & 01171300 & Massachusetts & 37 & -0.52 & 0.18 & Yes \\
\hline 109 & 01171500 & Massachusetts & 73 & -0.34 & 0.09 & Yes \\
\hline 110 & 01173500 & Massachusetts & 45 & 1.78 & 0.45 & Yes \\
\hline 111 & 01174000 & Massachusetts & 35 & -0.47 & 0.18 & Yes \\
\hline 112 & 01174500 & Massachusetts & 75 & 0.80 & 0.12 & Yes \\
\hline 113 & 01174900 & Massachusetts & 36 & -0.28 & 0.16 & Yes \\
\hline 114 & 01175670 & Massachusetts & 51 & 0.00 & 0.10 & Yes \\
\hline 115 & 01176000 & Massachusetts & 99 & 1.58 & 0.26 & Yes \\
\hline 116 & 01179500 & Massachusetts & 32 & 0.76 & 0.23 & Yes \\
\hline 117 & 01180000 & Massachusetts & 29 & 0.39 & 0.21 & No-P \\
\hline 118 & 01180500 & Massachusetts & 54 & 0.95 & 0.18 & Yes \\
\hline 119 & 01181000 & Massachusetts & 76 & 0.37 & 0.09 & Yes \\
\hline 120 & 01185500 & Massachusetts & 98 & 1.05 & 0.14 & Yes \\
\hline
\end{tabular}


Table 1. Streamgages in Connecticut, Maine, Massachusetts, New Hampshire, Rhode Island, Vermont, and easternmost New York used in the New England regional skew analysis.-Continued

[USGS, U.S. Geological Survey; EMA, expected moments algorithm; MSE, mean squared error; No-R, streamgage not used in regional skew analysis because of redundancy; No-P, streamgage not used in regional skew analysis because the pseudorecord length $\left(\mathrm{P}_{R L}\right)$ was less than 30 years]

\begin{tabular}{|c|c|c|c|c|c|c|}
\hline \multirow{2}{*}{$\begin{array}{l}\text { Regional skew } \\
\text { index number }\end{array}$} & \multirow{2}{*}{$\begin{array}{c}\text { USGS } \\
\text { streamgage } \\
\text { number }\end{array}$} & \multirow{2}{*}{$\begin{array}{l}\text { State where } \\
\text { streamgage } \\
\text { is located }\end{array}$} & \multirow[b]{2}{*}{$\boldsymbol{P}_{R L}$} & \multicolumn{2}{|c|}{ EMA analysis } & \multirow{2}{*}{$\begin{array}{l}\text { Used in regional } \\
\text { skew model }\end{array}$} \\
\hline & & & & $\begin{array}{c}\text { Skew, } \\
\text { in log units }\end{array}$ & $\begin{array}{l}\text { MSE of skew, } \\
\text { in log units }\end{array}$ & \\
\hline 121 & 01197000 & Massachusetts & 76 & 0.25 & 0.08 & No-R \\
\hline 122 & 01197500 & Massachusetts & 76 & 0.40 & 0.09 & Yes \\
\hline 123 & 01198000 & Massachusetts & 28 & 0.84 & 0.15 & No-P \\
\hline 124 & 01331500 & Massachusetts & 79 & 0.69 & 0.11 & Yes \\
\hline 125 & 01332000 & Massachusetts & 63 & 0.50 & 0.12 & Yes \\
\hline 126 & 01333000 & Massachusetts & 62 & -0.05 & 0.09 & Yes \\
\hline 127 & 01333500 & New York & 64 & 0.53 & 0.12 & Yes \\
\hline 128 & 01334500 & New York & 100 & 0.82 & 0.10 & No-R \\
\hline 129 & 01360640 & New York & 21 & -0.65 & 0.30 & No-P \\
\hline 130 & 01052500 & New Hampshire & 70 & 0.37 & 0.10 & Yes \\
\hline 131 & 01064300 & New Hampshire & 41 & 0.24 & 0.14 & Yes \\
\hline 132 & 01064400 & New Hampshire & 28 & -0.14 & 0.19 & No-P \\
\hline 133 & 01064500 & New Hampshire & 88 & -0.11 & 0.05 & No-R \\
\hline 134 & 01065000 & New Hampshire & 62 & 0.23 & 0.09 & No-R \\
\hline 135 & 01073000 & New Hampshire & 77 & 0.18 & 0.08 & Yes \\
\hline 136 & 01073500 & New Hampshire & 77 & 0.41 & 0.09 & Yes \\
\hline 137 & 01073600 & New Hampshire & 47 & 0.29 & 0.12 & Yes \\
\hline 138 & 01074520 & New Hampshire & 49 & 0.10 & 0.07 & Yes \\
\hline 139 & 01075800 & New Hampshire & 35 & 0.49 & 0.19 & Yes \\
\hline 140 & 01076500 & New Hampshire & 108 & 0.39 & 0.07 & Yes \\
\hline 141 & 01078000 & New Hampshire & 122 & 0.42 & 0.06 & Yes \\
\hline 142 & 01082000 & New Hampshire & 68 & 0.38 & 0.09 & Yes \\
\hline 143 & 01084000 & New Hampshire & 50 & 0.74 & 0.11 & Yes \\
\hline 144 & 01084500 & New Hampshire & 63 & 0.48 & 0.11 & Yes \\
\hline 145 & 01085800 & New Hampshire & 49 & 0.06 & 0.11 & Yes \\
\hline 146 & 01086000 & New Hampshire & 52 & 0.33 & 0.09 & Yes \\
\hline 147 & 01089100 & New Hampshire & 59 & 0.12 & 0.09 & Yes \\
\hline 148 & 01089500 & New Hampshire & 62 & 0.59 & 0.09 & Yes \\
\hline 149 & 01091000 & New Hampshire & 44 & 1.11 & 0.18 & Yes \\
\hline 150 & 01093800 & New Hampshire & 41 & 0.26 & 0.14 & Yes \\
\hline 151 & 01094000 & New Hampshire & 160 & 0.45 & 0.05 & Yes \\
\hline 152 & 01127880 & New Hampshire & 21 & -0.43 & 0.27 & No-P \\
\hline 153 & 01130000 & New Hampshire & 71 & -0.17 & 0.08 & Yes \\
\hline 154 & 01133000 & New Hampshire & 70 & 0.84 & 0.12 & Yes \\
\hline 155 & 01134500 & New Hampshire & 65 & 0.37 & 0.10 & Yes \\
\hline 156 & 01135150 & New Hampshire & 21 & 1.49 & 0.56 & No-P \\
\hline 157 & 01135300 & New Hampshire & 21 & 1.25 & 0.45 & No-P \\
\hline 158 & 01135500 & New Hampshire & 83 & 0.36 & 0.08 & Yes \\
\hline 159 & 01137500 & New Hampshire & 72 & 0.24 & 0.09 & Yes \\
\hline 160 & 01139000 & New Hampshire & 71 & 0.25 & 0.09 & Yes \\
\hline
\end{tabular}


Table 1. Streamgages in Connecticut, Maine, Massachusetts, New Hampshire, Rhode Island, Vermont, and easternmost New York used in the New England regional skew analysis. - Continued

[USGS, U.S. Geological Survey; EMA, expected moments algorithm; MSE, mean squared error; No-R, streamgage not used in regional skew analysis because of redundancy; No-P, streamgage not used in regional skew analysis because the pseudorecord length $\left(\mathrm{P}_{R L}\right)$ was less than 30 years]

\begin{tabular}{cclcccc}
\hline \multirow{2}{*}{$\begin{array}{c}\text { Regional skew } \\
\text { index number }\end{array}$} & $\begin{array}{c}\text { USGS } \\
\text { streamgage } \\
\text { number }\end{array}$ & $\begin{array}{c}\text { State where } \\
\text { streamgage } \\
\text { is located }\end{array}$ & $\boldsymbol{P}_{\boldsymbol{R L}}$ & $\begin{array}{c}\text { EMA analysis } \\
\text { Skew, } \\
\text { in log units }\end{array}$ & $\begin{array}{c}\text { MSE of skew, } \\
\text { in log units }\end{array}$ & $\begin{array}{c}\text { Used in regional } \\
\text { skew model }\end{array}$ \\
\hline 161 & 01139800 & New Hampshire & 53 & 0.19 & 0.11 & Yes \\
162 & 01141800 & New Hampshire & 39 & 0.04 & 0.13 & Yes \\
163 & 01142500 & New Hampshire & 163 & 0.97 & 0.08 & Yes \\
164 & 01144000 & New Hampshire & 96 & 0.99 & 0.13 & Yes \\
165 & 01145000 & New Hampshire & 71 & -0.17 & 0.08 & Yes \\
166 & 01150900 & New Hampshire & 84 & 1.94 & 0.36 & Yes \\
167 & 01152500 & New Hampshire & 83 & 0.24 & 0.08 & Yes \\
168 & 01153550 & New Hampshire & 69 & 0.37 & 0.10 & Yes \\
169 & 01154000 & New Hampshire & 58 & 0.79 & 0.16 & Yes \\
170 & 01155000 & New Hampshire & 46 & 0.54 & 0.16 & Yes \\
171 & 01157000 & New Hampshire & 64 & 0.74 & 0.15 & Yes \\
172 & 01160000 & New Hampshire & 60 & 0.71 & 0.15 & Yes \\
173 & 01329000 & Vermont & 80 & 0.45 & 0.09 & Yes \\
174 & 01334000 & Vermont & 80 & 0.04 & 0.07 & Yes \\
175 & 04280000 & Vermont & 83 & 0.24 & 0.08 & Yes \\
176 & 04280350 & Vermont & 25 & -0.01 & 0.20 & No-P \\
177 & 04282000 & Vermont & 83 & -0.12 & 0.07 & Yes \\
178 & 04282650 & Vermont & 22 & -0.01 & 0.22 & No-P \\
179 & 04282780 & Vermont & 22 & 0.31 & 0.25 & No-P \\
180 & 04282795 & Vermont & 22 & 0.03 & 0.23 & No-P \\
181 & 04287000 & Vermont & 78 & 0.25 & 0.08 & Yes \\
182 & 04288000 & Vermont & 164 & 0.76 & 0.06 & Yes \\
183 & 04292000 & Vermont & 85 & 0.11 & 0.06 & Yes \\
184 & 04292700 & Vermont & 23 & 0.52 & 0.18 & No-P \\
185 & 04296000 & Vermont & 60 & -0.02 & 0.09 & Yes \\
186 & 010965852 & Vermont & 25 & 0.17 & 0.21 & No-P \\
\hline
\end{tabular}




\section{Appendix 1. Assessment of New England Regional Skew Constant Model Through Monte Carlo Realizations}

The Monte Carlo simulations presented in this appendix address whether the apparent observed geospatial structure in the station skewness coefficient (skews; fig. 1-1) is evidence of model misspecification or is an artifact of random sampling variability, possibly confounded by the covariance structure of the errors. The Monte Carlo simulations were generated from a multivariate normal distribution with a mean equal to the constant from the New England regional skew constant model and a covariance matrix identical to the covariance matrix from the New England regional skew model. Both the mean and covariance of the multivariate normal distribution from which samples were drawn are described in detail below.

Observed, unbiased at-site skews developed for the New England Bayesian weighted least squares/Bayesian generalized least squares (B-WLS/B-GLS) regional skew constant

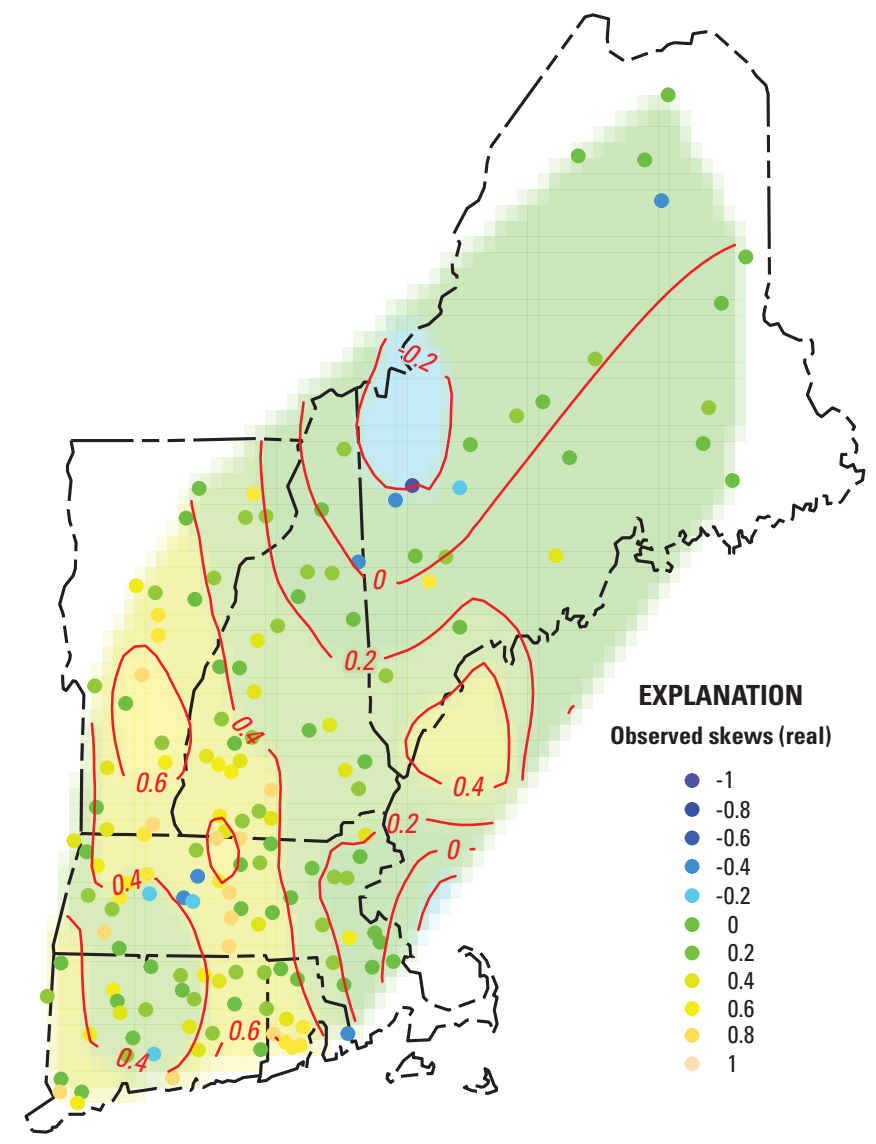

Figure 1-1. Map of at-site unbiased (unweighted) skews computed at 186 streamgages used to develop a regional skew for New England. The contour lines and shading provide a sense of geographic patterns in the skews. model described in this report are depicted in figure 1-1, along with contour lines and shading to provide a sense of geographic patterns in the skews. The contouring algorithm used to generate the map in figure 1-1 shows a substantial amount of geospatial structure in the pattern of the unbiased at-site skews. In particular, the smaller skews (negative skews) in Maine, especially in northern and northwestern Maine (shaded blue and green), might be a cause for concern that a constant model is not representing all the observed variability in skew.

The skew $\hat{\gamma}_{B W L S / B G L S}$ from the constant model for the New England regional skew (table 2) is calculated from the following:

$$
\hat{\gamma}_{B W L S / B G L S}=0.37+\varepsilon,
$$

where $\varepsilon$ represents the total error, calculated as follows:

$$
\varepsilon \sim N(0, \operatorname{Var}(\varepsilon)),
$$

where $N$ signifies a normal distribution of the total error in constant regional skew model determined in the B-GLS analysis. As described in equation $23, \operatorname{Var}(\varepsilon)$ can be described as follows:

$$
\varepsilon \varepsilon^{T}=\Lambda_{G L S}\left(\sigma_{\delta, B-G L S}^{2}\right)=\sigma_{\delta, B-G L S}^{2} I+\sum \hat{\gamma}
$$

where

$$
\begin{gathered}
\Lambda_{G L S}\left(\sigma_{\delta, B-G L S}^{2}\right) \text { is the } n \times n \text { GLS covariance matrix, } \\
\begin{array}{cl}
\sigma_{\delta, B-G L S}^{2} & \begin{array}{r}
\text { is the B-GLS variance of the underlying } \\
\text { model error } \delta,
\end{array} \\
I & \text { is an } n \times n \text { identity matrix, and } \\
\sum \hat{\gamma} & \begin{array}{l}
\text { is the full } n \times n \text { covariance matrix of the } \\
\text { sampling errors for each streamgage }(i) .
\end{array}
\end{array}
\end{gathered}
$$

The covariance matrix of the sampling errors is made up of the sampling variances of the unbiased at-site skew $\left(\operatorname{Var}\left[\hat{\gamma}_{i}\right]\right)$ and the covariances of skew estimators $\left(\hat{\gamma}_{i}\right)$. The off-diagonal values of $\Sigma(\hat{\gamma})$ are determined by the cross correlation of concurrent systematic annual peak flows and the $c f$ factor that accounts for the sample size difference between streamgages and their concurrent record length (eq. 17; Martins and Stedinger, 2002, eq. 3).

The model error variance $\sigma_{\delta}^{2}$ for the New England regional skew constant model is 0.13 (table 2), which was used in the Monte Carlo simulations. The covariance matrix $\Sigma(\hat{\gamma})$ used in the Monte Carlo simulations is the same as the one used in the B-WLS/B-GLS (eq. 25). 
The results of the Monte Carlo simulations are depicted graphically (fig. 1-2) in twenty realizations of the expected patterns in the station skew if the station skews are normally distributed with a mean equal to 0.37 and with the $\operatorname{Var}(\varepsilon)$ given by equation 35 . The Monte Carlo simulations reveal no consistent spatial pattern of the station skews, consistent with the observed pattern of the station skews of the constant model (figs. 1-1 and 1-2). Therefore, there is little evidence of a lack of fit based on the geographic patterns observed in the station skews.

Figure 1-2. Results of $A-T$, twenty Monte Carlo simulations of skews at 153 streamgages in New England. Simulations were generated from a multivariate normal distribution with a mean equal to the constant (0.37) from the New England regional skew model and a covariance matrix identical to the covariance matrix from the New England regional skew model. The contour lines and shading provide a sense of geographic patterns in the skews.

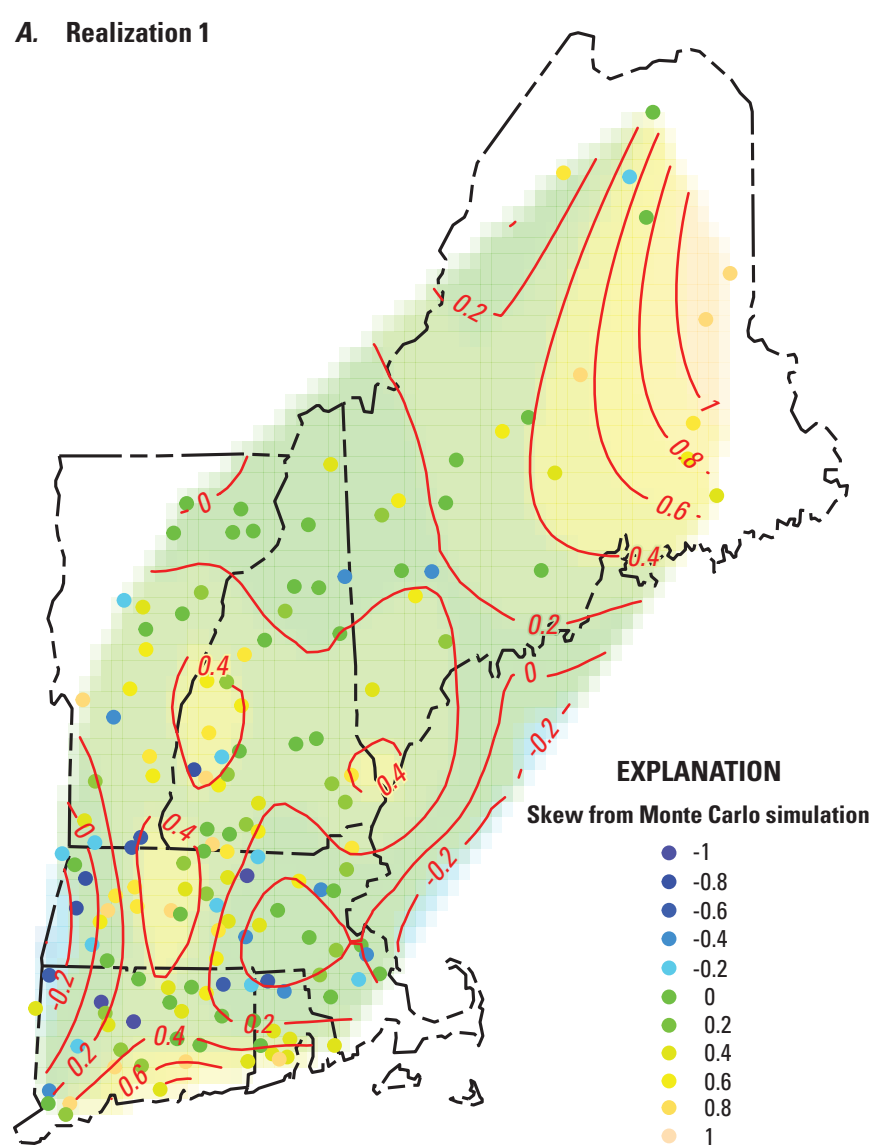

B. Realization 2

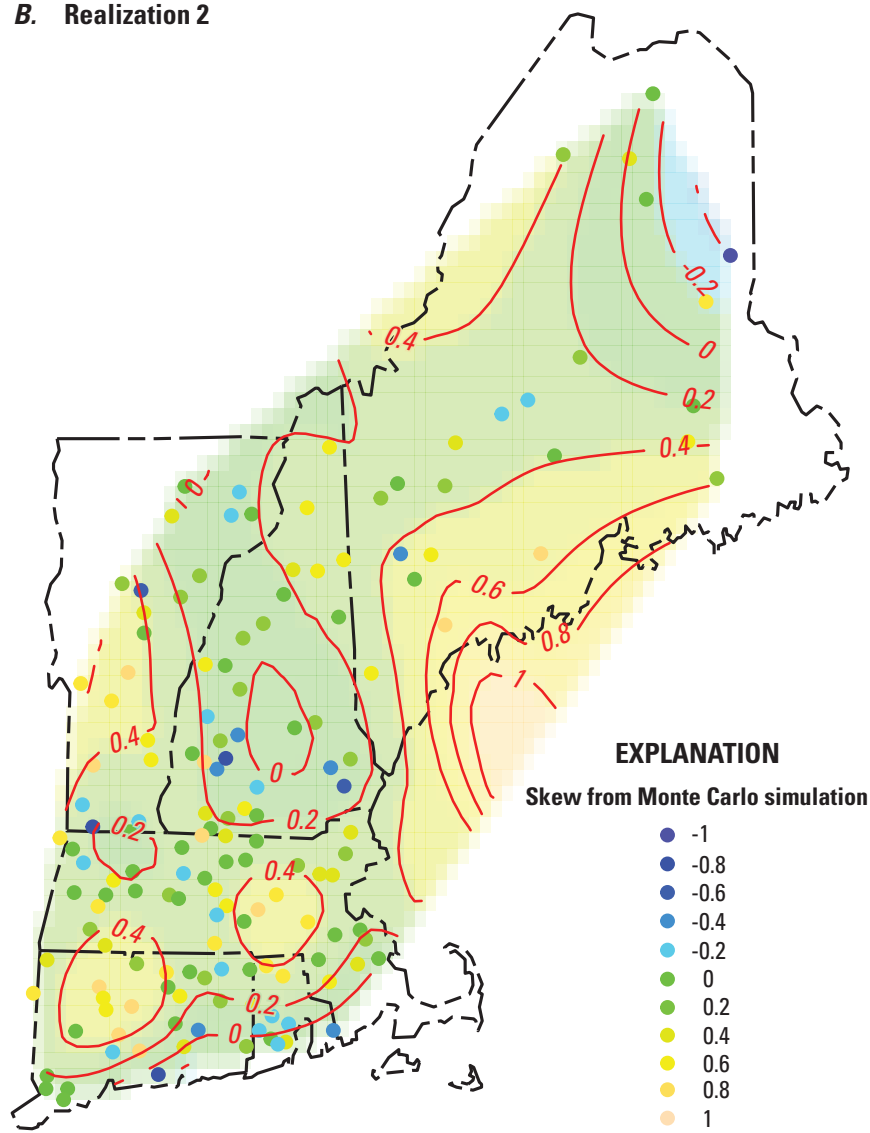



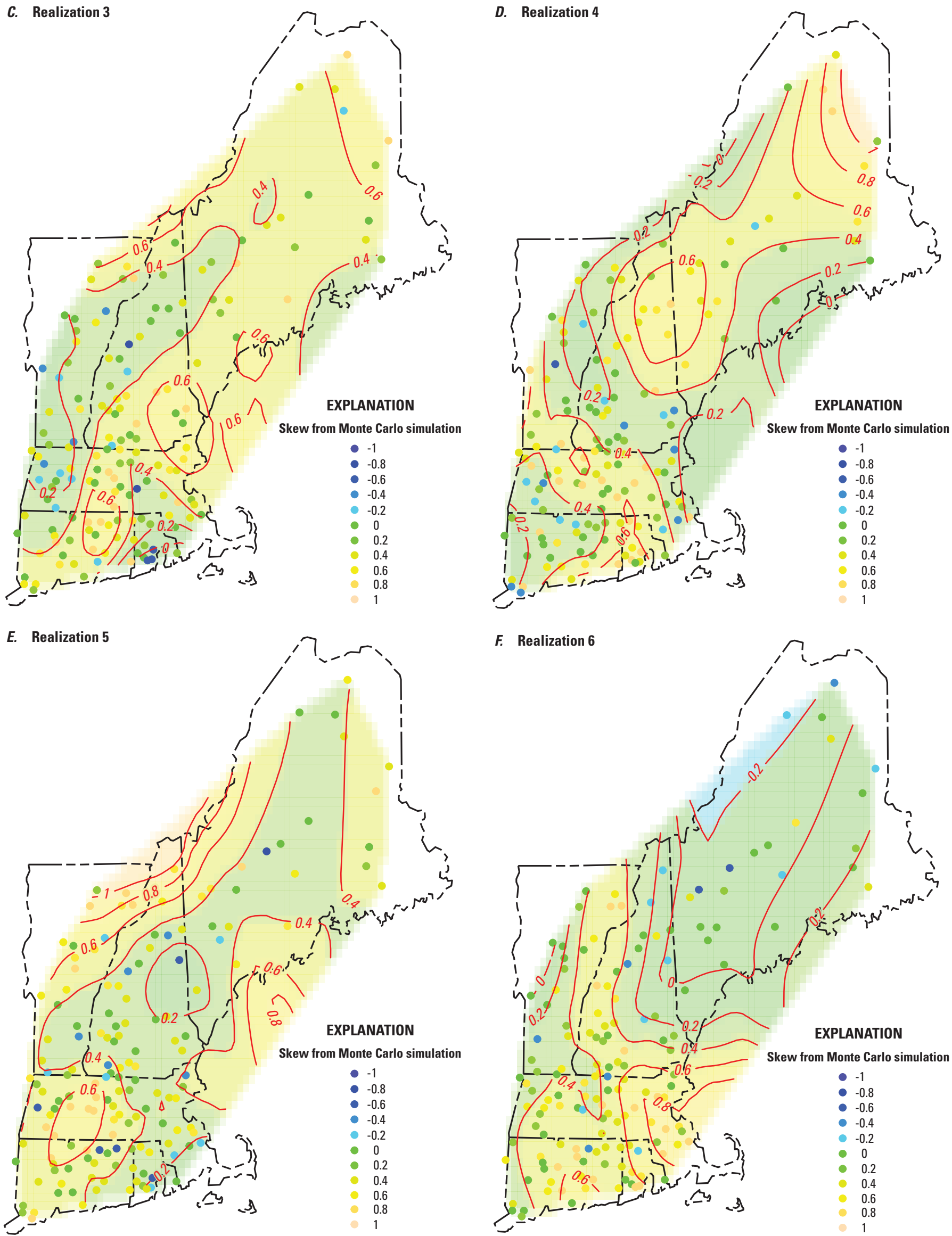

Figure 1-2.-Continued 
G. Realization 7
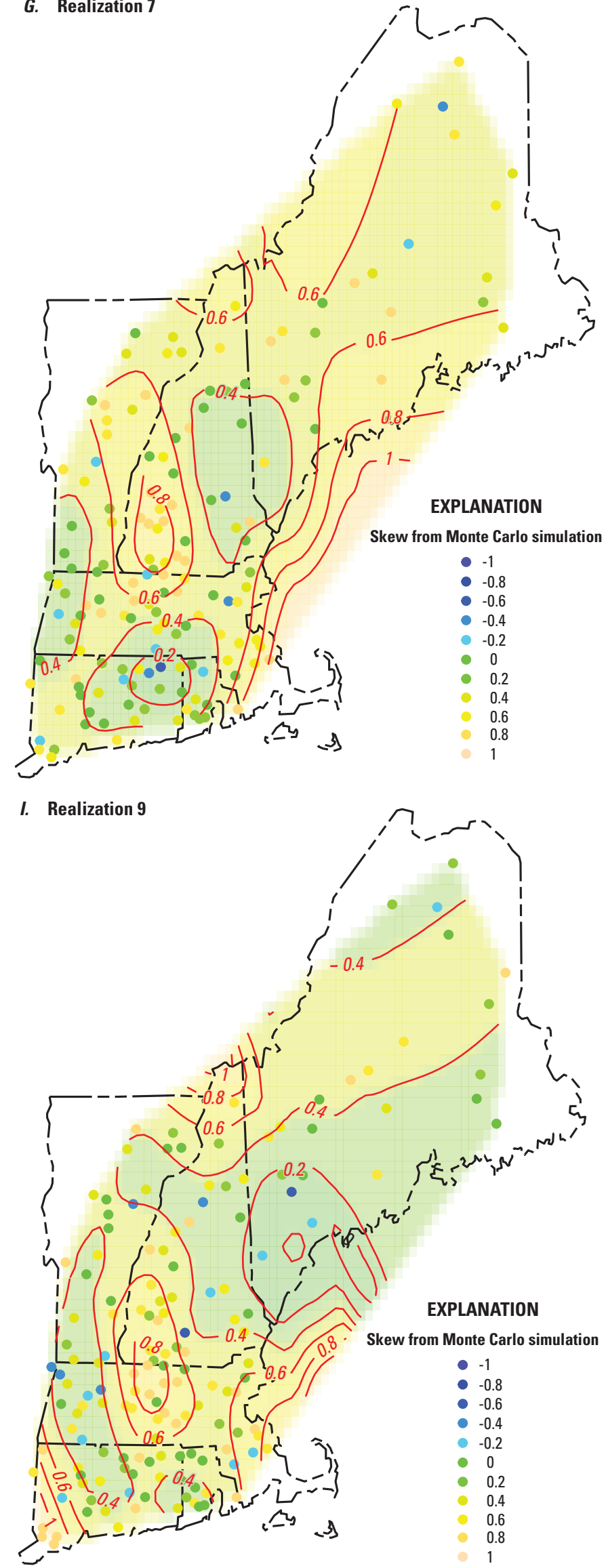

H. $\quad$ Realization 8

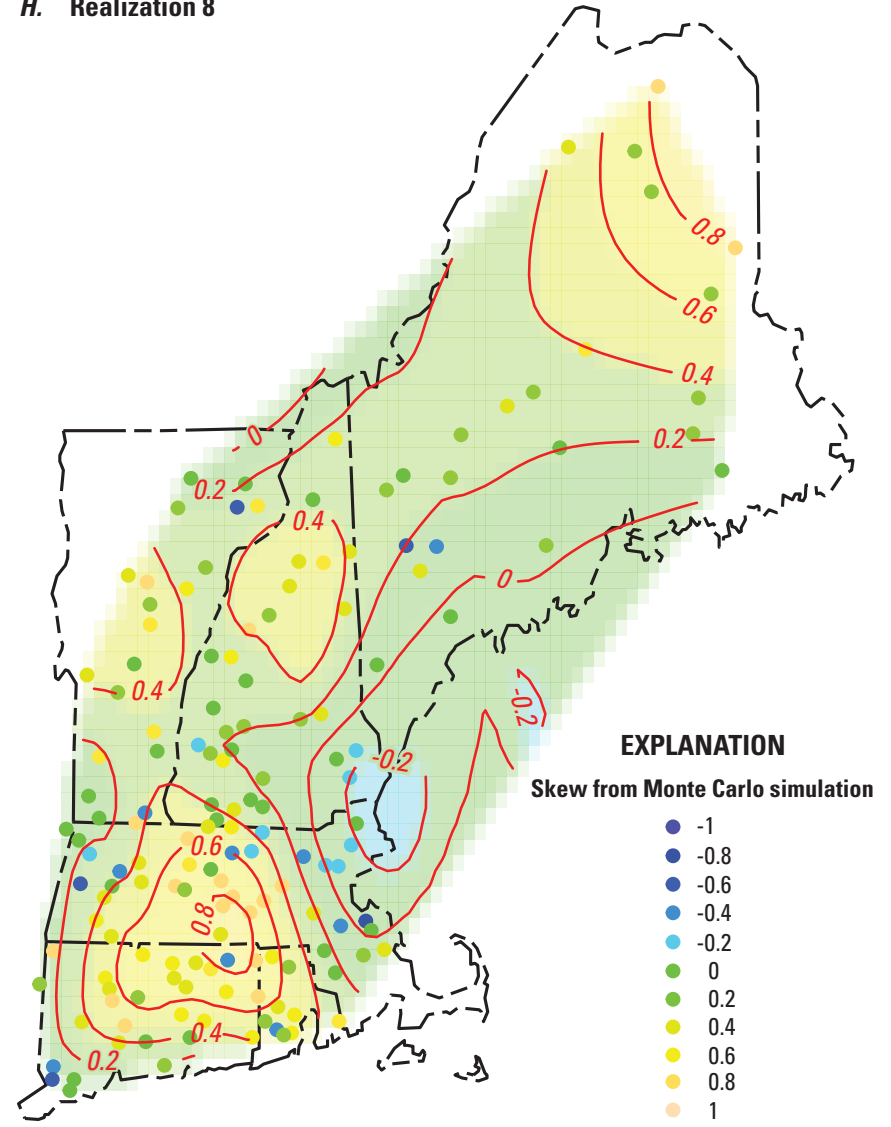

Figure 1-2.-Continued 

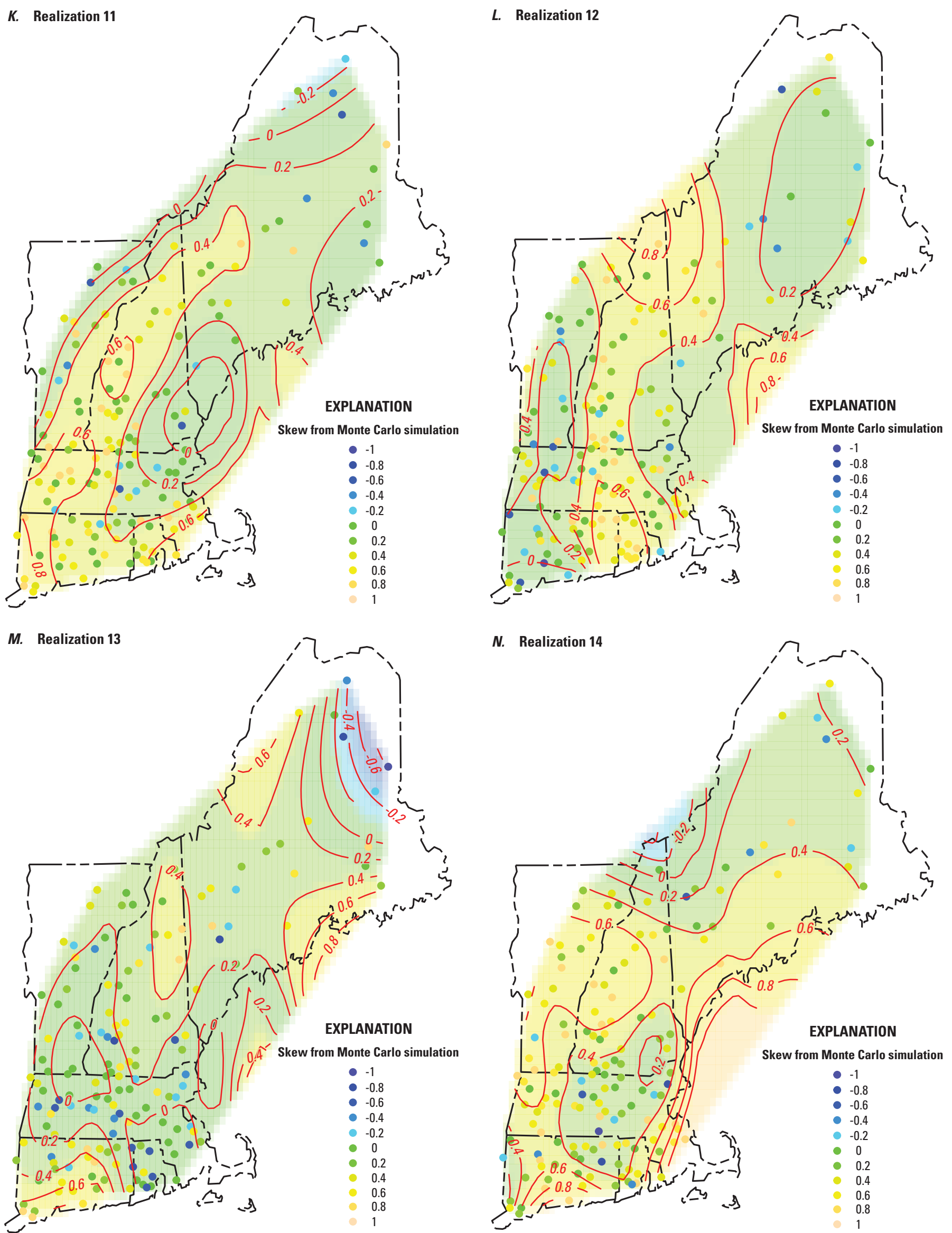

Figure 1-2.-Continued 

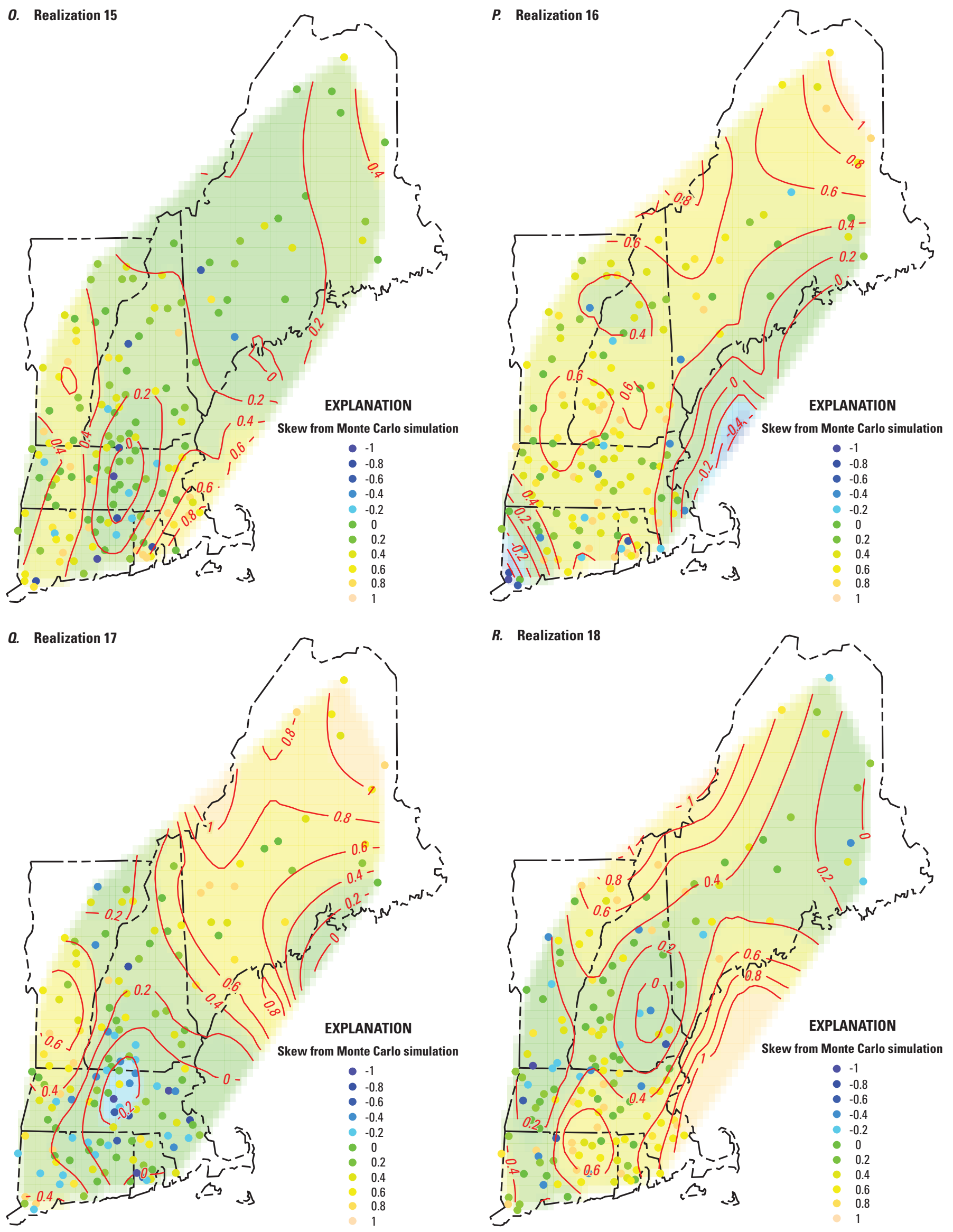

Figure 1-2.-Continued 
S. Realization 19

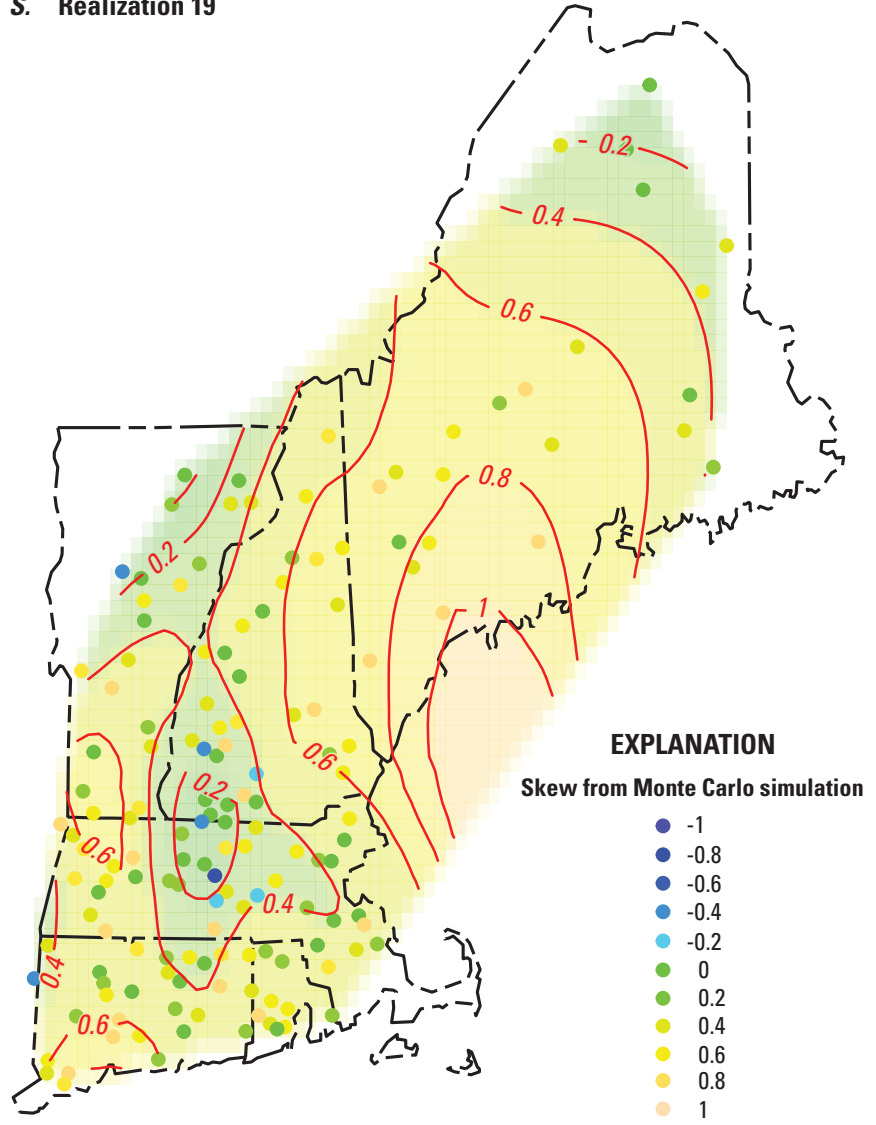

T. Realization 20

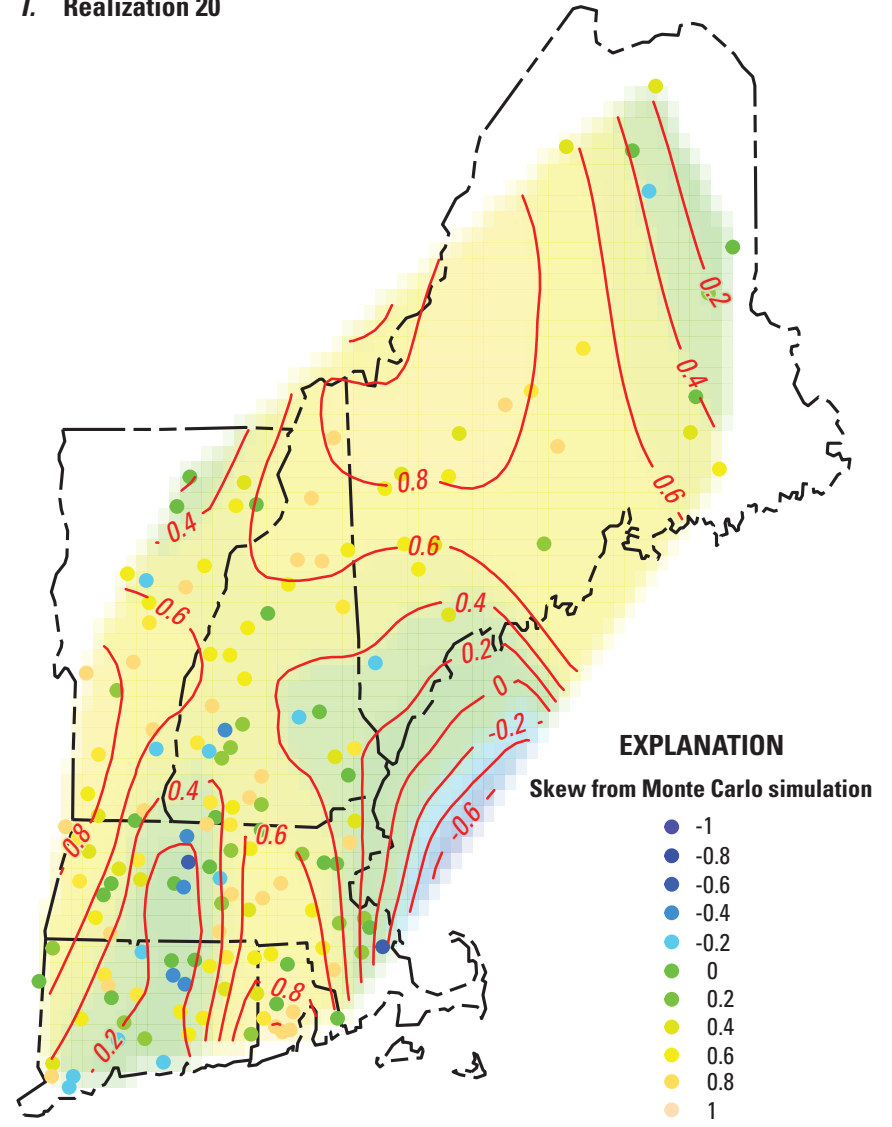

Figure 1-2.-Continued 

For more information about this report, contact: U.S. Geological Survey

Integrated Modeling and Prediction Division

Water Mission Area

12201 Sunrise Valley Drive, MS 415

Reston, VA 20192

Publishing support provided by the

Pembroke Publishing Service Center 
